\title{
A Modified Aerosol Free Vegetation Index Algorithm for Aerosol Optical Depth Retrieval Using GOSAT TANSO-CAI Data
}

\author{
Guosheng Zhong ${ }^{1, *}$, Xiufeng Wang ${ }^{2}$, Hiroshi Tani ${ }^{2}$, Meng Guo ${ }^{3}$, Anthony R. Chittenden ${ }^{4}$, \\ Shuai Yin ${ }^{1}$, Zhongyi Sun ${ }^{1}$ and Shinji Matsumura ${ }^{5}$ \\ 1 Graduate School of Agriculture, Hokkaido University, Sapporo 0608589, Japan; \\ yinshuai@env.agr.hokudai.ac.jp (S.Y.); sunzy025@env.agr.hokudai.ac.jp (Z.S.) \\ 2 Research Faculty of Agriculture, Hokkaido University, Sapporo 0608589, Japan; \\ wang@env.agr.hokudai.ac.jp (X.W.); tani@env.agr.hokudai.ac.jp (H.T.) \\ 3 School of Geographical Sciences, Northeast Normal University, Changchun 130024, China; \\ guom521@nenu.edu.cn \\ 4 Faculty of Fisheries Sciences, Hokkaido University, Hakodate 0418611, Japan; archi@fish.hokudai.ac.jp \\ $5 \quad$ Faculty of Agriculture, Kagawa University, Kagawa 7610795, Japan; matsu@ag.kagawa-u.ac.jp \\ * Correspondence: zhgs@env.agr.hokudai.ac.jp; Tel.: +81-11-706-3659
}

Academic Editors: Alexander A. Kokhanovsky, Richard Müller and Prasad S. Thenkabail

Received: 22 September 2016; Accepted: 29 November 2016; Published: 7 December 2016

\begin{abstract}
In this paper, we introduced a new algorithm for retrieving aerosol optical depth (AOD) over land, from the Cloud and Aerosol Imager (CAI), which is one of the instruments on the Greenhouse Gases Observing Satellite (GOSAT) for detecting and correcting cloud and aerosol interference. We used the GOSAT and AErosol RObotic NETwork (AERONET) collocated data from different regions over the globe to analyze the relationship between the top-of-atmosphere (TOA) reflectance in the shortwave infrared $(1.6 \mu \mathrm{m})$ band and the surface reflectance in the red $(0.67 \mu \mathrm{m})$ band. Our results confirmed that the relationships between the surface reflectance at $0.67 \mu \mathrm{m}$ and TOA reflectance at $1.6 \mu \mathrm{m}$ are not constant for different surface conditions. Under low AOD conditions (AOD at $0.55 \mu \mathrm{m}<0.1$ ), a Normalized Difference Vegetation Index (NDVI) based regression function for estimating the surface reflectance of $0.67 \mu \mathrm{m}$ band from the $1.6 \mu \mathrm{m}$ band was summarized, and it achieved good performance, proving that the reflectance relations of the $0.67 \mu \mathrm{m}$ and $1.6 \mu \mathrm{m}$ bands are typically vegetation dependent. Since the NDVI itself is easily affected by aerosols, we combined the advantages of the Aerosol Free Vegetation Index (AFRI), which is aerosol resistant and highly correlated with regular NDVI, with our regression function, which can preserve the various correlations of $0.67 \mu \mathrm{m}$ and $1.6 \mu \mathrm{m}$ bands for different surface types, and developed a new surface reflectance and aerosol-free NDVI estimation algorithm, which we named the Modified AFRI $_{1.6}$ algorithm. This algorithm was applied to AOD retrieval, and the validation results for our algorithm show that the retrieved AOD has a consistent relationship with AERONET measurements, with a correlation coefficient of 0.912 , and approximately $67.7 \%$ of the AOD retrieved data were within the expected error range $\left( \pm 0.1 \pm 0.15 \mathrm{AOD}_{(\mathrm{AERONET})}\right)$.
\end{abstract}

Keywords: AOD retrieval; GOSAT CAI; Modified AFRI 1.6 algorithm; surface reflectance

\section{Introduction}

Aerosols have a considerable influence on the radiative balance of the Earth and global climate change through the absorption and scattering of solar radiation [1-3]. Particularly, atmospheric aerosol particles are closely associated with public health and the environment (e.g., the tropospheric aerosols, also known as particulate matter, PM) [4-6]. One important aerosol optical property, aerosol optical 
depth (AOD), can reflect the characteristics of atmospheric turbidity and is the most frequently used monitoring parameter of atmospheric aerosols [7].

Satellite remote-sensing techniques are very effective for observing the spatial distributions and temporal variations of aerosol optical properties on a large scale [8]. Various satellite sensors have been applied to retrieve AOD [9-11], even though these sensors are not initially intended for aerosol monitoring [12]. The estimation of AOD has benefited from the development of algorithms for sensors with different wavelengths, viewing angles and polarizations [13,14].

Removal of the surface contribution has long been considered the primary task for estimating the optical properties of aerosols [14,15]. Due to the complexities of the land surface, aerosol retrieval over land is much more difficult compared to retrieval over ocean. Currently, several methods have been developed to remove the land surface contribution in satellite remote sensing. Among these, the Dark Target (DT) algorithm has been widely used for aerosol retrieval and has been successfully applied to different satellite sensors, such as Moderate-Resolution Imaging Spectroradiometer (MODIS) [16,17], Advanced Very High Resolution Radiometer (AVHRR) [18] and Visible infrared Imaging Radiometer (VIIRS) [19]. The DT algorithm is based on the assumption that aerosols will brighten the scene over "dark" surfaces (vegetated land and dark ocean). Generally, the dark surfaces have low surface reflectances in parts of the visible and shortwave infrared (SWIR) channels, and the low surface contribution benefits the determination of contribution of aerosols. The MODIS DT algorithm uses the linear relationships between the surface reflectance of the SWIR $(2.1 \mu \mathrm{m})$ channel (negligibly affected by aerosols at this wavelength) and the red or blue channels to account for the surface signal in the corresponding channel. This method works best over dark vegetated surfaces, but not over bright land surfaces. This is because the top-of-atmosphere (TOA) reflectances acquired by satellite sensors over bright land surfaces are overwhelmed by the surface contributions, making it very difficult to estimate the contribution of aerosols [20,21]. The development of the Deep Blue algorithm has made up the gap in aerosols retrieval over bright land surface; the Deep Blue algorithm successfully performed aerosols retrieval over bright targets as well as over most vegetated targets [21,22]. The precalculated surface reflectance database in the blue channels is the prerequisite of the Deep Blue algorithm, and it is a complicated task to develop a reflectance database for other sensors. Despite the MODIS DT algorithm having been proven to be a mature algorithm for AOD retrieving, sensors without a $2.1 \mu \mathrm{m}$ channel onboard cannot rely on this algorithm to estimate the surface reflectance of red or blue channels. Therefore, different strategies were developed for the instruments that do not measure reflectance in the $2.1 \mu \mathrm{m}$ channel. In the synergetic aerosol retrieval (SYNAER) method [14,23], Holzer-Popp et al. introduced a Normalized Difference Vegetation Index (NDVI) and scattering angle-involved iterative regression function for estimating the surface reflectance at $0.67 \mu \mathrm{m}$ from the apparent reflectance of the $1.6 \mu \mathrm{m}$ band $[23,24]$. This method was carried out with Advanced Along-Track Scanning Radiometer (AATSR) and Scanning Imaging Absorption Spectrometer for Atmospheric CHartographY (SCIAMACHY) sensors onboard ENVISAT used for AOD retrieval [23-25]. Similarly, Mei et al. derived an approach to estimate surface reflectance at $0.67 \mu \mathrm{m}$ from the apparent reflectance at $3.75 \mu \mathrm{m}$ from the AVHRR data based on NDVI. In their algorithms, the NDVI is used to determine the dark fields and tune the ratios and relationships between the $0.67 \mu \mathrm{m}$ and the $1.6 \mu \mathrm{m}$ or $3.75 \mu \mathrm{m}$ bands under different surface conditions [26]. Nevertheless, aerosols easily influence NDVI, and increasing AOD would typically result in the decrease of NDVI values $[27,28]$. To eliminate the errors in NDVI caused by aerosols, an additional one-step iteration was performed to adjust the NDVI value [23-26,29]. Compared with non-iterative retrieval algorithms, the iteration step will increase the computational cost of retrieval. Therefore, replacing NDVI with the Aerosol Free Vegetation Index (AFRI) has the potential to simplify the retrieval process.

In our study, the data from Greenhouse Gases Observing Satellite (GOSAT) were used for AOD retrieval. GOSAT is the world's first spacecraft to retrieve the concentrations of carbon dioxide and methane. Thermal and Near-infrared Sensor for carbon Observation Fourier Transform Spectrometer (TANSO-FTS) and Cloud \& Aerosol Imager (TANSO-CAI) are the observation instruments on board 
the satellite. TANSO-FTS is used to measure the total columns of carbon dioxide and methane [30]. One of the important responsibilities or functions of TANSO-CAI is to provide information about aerosols by visualizing the atmosphere and the ground surface to detect cirrus clouds and aerosols, which are then used to correct the TANSO-FTS data [31,32]. Many studies show that inaccurate aerosol information can result in significant errors in the retrieved column-averaged dry-air mole fractions of $\mathrm{CO} 2\left(\mathrm{XCO}_{2}\right)$ results, and information on aerosol optical properties has been considered the most substantial factor affecting the $\mathrm{XCO}_{2}$ retrieval algorithm [32,33]. However, since the TANSO-CAI does not have any definitive aerosol product, a priori information on aerosol as the input to the TANSO-FTS retrieval process is utilized from other platforms [34]. Because the atmosphere is constantly changing, different platforms will inevitably bring uncertainty due to their observation conditions and spatial-temporal differences. Therefore, as the onboard instruments use the same platform as TANSO-FTS, the development of the aerosol retrieval algorithm for TANSO-CAI can take full advantage of their spatial-temporal consistency and fulfill the requirement of obtaining more accurate aerosol information for the TANSO-FTS retrieval process. An AOD retrieval algorithm can extend the function of TANSO-CAI to the AOD observations to provide one-platform combination data (including carbon dioxide, methane and AOD) for future studies on the relationship between greenhouse gases and aerosols. Moreover, the AOD observations also play a key role for estimating ground-level PM2.5 concentrations [35]. The improvements of aerosol and chemical transport model have proliferated the assimilation of aerosol data, which can analyze and forecast dust storms and general air quality [36,37].

In this paper, we mainly describe a non-iterative AOD retrieval algorithm over land using the GOSAT TANSO-CAI red $(0.67 \mu \mathrm{m})$, near infrared (NIR, $0.87 \mu \mathrm{m})$ and SWIR $(1.6 \mu \mathrm{m})$ bands. An important part of this work was the development of a surface reflectance estimation algorithm based on the analysis of TANSO-CAI and AErosol Robotic Network (AERONET) collocated data from different ground stations located in different global regions (described in Section 3). The AOD retrieval was based on a look-up table method that was established using a radiative transfer model, and the evaluation of the retrieval algorithm was conducted by comparing the retrieved AOD and AERONET AOD (described in Section 4).

\section{General Principle}

For Lambertain surfaces under a cloud-free and vertically homogeneous atmosphere, the physical processes of reflection, scattering and absorption of solar radiation are described by Equation (1).

$$
\mathrm{R}_{\mathrm{TOA}}\left(\lambda, \mu_{0}, \mu, \varphi\right)=\mathrm{R}_{\text {Path }}\left(\lambda, \mu_{0}, \mu, \varphi\right)+\frac{\mathrm{R}_{\mathrm{Surf}}(\lambda) \mathrm{T}_{d}\left(\lambda, \mu_{0}\right) \mathrm{T}_{\mathrm{u}}(\lambda, \mu)}{1-\mathrm{R}_{\text {Surf }}(\lambda) \mathrm{S}(\lambda)}
$$

where $\mu_{0}, \mu$ and $\varphi$ are the cosine of the solar zenith angle, the cosine of the satellite zenith angle and the relative azimuth angle between the sun and satellite, respectively; $\mathrm{R}_{\mathrm{TOA}}$ is the TOA reflectance at a given wavelength $\lambda ; R_{\text {Path }}$ is the atmospheric "path reflectance", which includes the molecular and aerosol scattering; $R_{\text {surf }}$ is the angular "surface reflectance"; $S$ is the atmospheric hemispherical albedo; $\mathrm{T}_{\mathrm{d}}$ is the atmospheric transmittance from TOA to surface; and $\mathrm{T}_{\mathrm{u}}$ is the atmospheric transmission from the surface to TOA. From Equation (1), the TOA reflectance received by the satellite sensor can be regarded as the joint contribution of surface and atmosphere [20,38].

Three very important atmospheric parameters are $R_{P a t h}, T_{d} T_{u}$ and $S$, and they are functions of AOD. When the aerosol model is determined, multiple sets of $R_{P a t h}, T_{d} T_{u}$ and $S$ values can be precomputed according to pre-defined combinations of AODs and geometrical conditions using the radiative transfer model. Then, a look-up table can be established for AOD retrieval [39-41].

When using the look-up table to retrieve AOD, the geometric parameters in the look-up table that are equal or closest to the geometric parameters of the satellite observations would be found. The selected geometric parameter set has multiple corresponding sets of atmospheric parameters: $R_{\text {Path, }} T_{d} T_{u}$ and $S$ with different AOD values. Each set of atmospheric parameters $R_{\text {Path, }} T_{d} T_{u}$ and $S$, along with the estimated surface reflectance, is substituted into Equation (1) to calculate the theoretical 
apparent reflectance. The theoretical apparent reflectances for the different parameter sets are compared with the actual apparent reflectance; to find the one that is closest to the actual apparent reflectance; its corresponding AOD will be considered the retrieved AOD.

In Equation (1), we can see that the three atmospheric parameters and the surface reflectance are critical to the retrieval accuracy. Among these, the atmospheric parameters are provided by the radiative transfer model, which in turn is determined by the surface reflectance estimation algorithm.

\section{Data and Algorithm}

\subsection{GOSAT TANSO-CAI}

The Greenhouse Gases Observing Satellite, developed by the Japan Aerospace Exploration Agency (JAXA), the Ministry of the Environment of Japan (MOE) and the National Institute for Environmental Studies (NIES) of Japan, was successfully launched on 23 January 2009 from Tanegashima Island, Japan [30,42]. GOSAT flies in a sun-synchronous orbit with a ground speed of $6.8 \mathrm{~km} / \mathrm{s}$ at an altitude of $666 \mathrm{~km}$ and maintains an inclination angle of $98^{\circ}$. Its period of revolution is approximately $1 \mathrm{~h}$ and 40 minutes, the local nadir overpass time is approximately 12:47 p.m., and it revisits the same point in space every three days with a total of 44 paths [42]. GOSAT carries two primary instruments, TANSO-FTS and the TANSO-CAI, to monitor the global distributions of carbon dioxide and methane and to detect clouds and aerosols [43].

The TANSO-CAI is a multichannel, narrow-band radiometer with ultraviolet (UV, band 1), visible (band 2), NIR (band 3) and SWIR (band 4) bands, used to capture daytime images of the atmosphere and ground. The center wavelengths of bands 1 to 4 are $0.38,0.67,0.87$ and $1.6 \mu \mathrm{m}$, respectively. Bands 1, 2 and 3 all have $20 \mu \mathrm{m}$ bandwidths, while band 4 has a $90 \mu \mathrm{m}$ bandwidth. Bands 1 to 3 have a $500 \mathrm{~m}$ spatial resolution at the nadir and a $1000 \mathrm{~km}$ observation swath; band 4 has a $1.5 \mathrm{~km}$ spatial resolution and a $750 \mathrm{~km}$ scan swath [42-44].

TANSO-CAI provides different processing-level radiances, cloud flag, global radiance and reflectance distribution, along with NDVI products [30]. The satellite data used in this study are the CAI L1B+ radiance data, and the radiance of each band has to be converted to reflectance for AOD retrieval [45]. In CAI L1B+ product, radiometric and geometric corrections (such as orthorectification, band-to-band registration and resampling) have been performed [46,47]. The observation information includes important geometric parameters for retrieval, such as the solar zenith/azimuth angle and satellite zenith/azimuth angle, which are recorded and added into the product data [48].

\subsection{AERONET AOD Data}

The AERONET [49] is a ground-based remote-sensing aerosol network with over 800 stations globally, providing long-term, continuous, standardized data on aerosol optical, microphysical and radiative properties. The AERONET obtains spectral AOD within the 0.34 to $1.02 \mu$ m wavelength range by direct Sun measurement with an accuracy of 0.01-0.02, and the AOD data are computed for three data quality levels: Level 1.0 (raw, unscreened), Level 1.5 (cloud-screened), and Level 2.0 (cloud-screened and quality-assured) [50,51]. In this study, extensive use of AERONET Level 2.0 AOD data was made for atmospheric correction and validation of satellite retrievals. Since the retrieved AOD is at the wavelength of $550 \mathrm{~nm}$, comparing TANSO-CAI AOD with AERONET AOD at the same wavelength requires that all AERONET AOD at other wavelengths should first be interpolated into $0.55 \mu \mathrm{m}$ using the Angstrom exponent, which can be calculated as follows [52]:

$$
\alpha=-\frac{\ln \left(\frac{\tau_{\lambda}}{\tau_{0.55}}\right)}{\ln \left(\frac{\lambda}{0.55}\right)}
$$

where $\tau_{\lambda}$ is the aerosol optical depth at a given wavelength $\lambda$, and $\alpha$ is the Angstrom exponent, the values of which are provided by AERONET measurement. 


\subsection{Atmospheric Correction of Collocated TANSO-CAI/AERONET Data}

To develop a surface reflectance (at $0.67 \mu \mathrm{m}$ ) estimation algorithm using the TOA reflectances at $1.6 \mu \mathrm{m}$, it is imperative to analyze the relationship between the satellite-measured reflectance and the surface reflectance by conducting accurate atmospheric correction.

Through atmospheric correction, we attempt to obtain information on atmospheric optical properties and then determine the real surface reflectance using the information from satellite observation [27]. Atmospheric correction primarily eliminates the impact of molecular and aerosol scattering and absorption by gases, such as water vapor, ozone, oxygen, and aerosols [53-56]. Molecular scattering and absorption by ozone and oxygen, which have relatively stable atmospheric concentrations, are not difficult to subtract. In addition, it is practical to correct the effects of water vapor by using climatology data or other satellite data. However, aerosols are the most difficult component to eliminate since their distributions are often heterogeneous [56].

Fortunately, the theoretical model of atmospheric radiative transfer can be used to account for the effects of the atmospheric components, including those mentioned above [57]. In this study, the 6S (Second Simulation of a Satellite Signal in the Solar Spectrum) radiative transfer model and the ground-measured AOD from AERONET were used to perform atmospheric correction on TANSO-CAI images. $6 \mathrm{~S}$ is an advanced radiative transfer code developed specifically for satellite applications [58]. It offers two main working modalities: simulation and atmospheric correction [59]. To run this code, a number of parameters are required as input: geometric conditions, atmospheric model, aerosol model and AOD, spectral conditions, ground reflectance type, and TOA reflectance/radiance. The atmospherically corrected reflectance/radiance and the relevant correction coefficients are output as results [60]. The continental aerosol model was selected as it can broadly describe both the scattering and absorption properties [16,61]. The atmospheric correction was performed on the arranged spatially and temporally matched TANSO-CAI/AERONET collocated data. The selection of TANSO-CAI/AERONET collocation data are based on the following criteria: GOSAT overpasses are within $15 \mathrm{~min}$ of the AERONET measurements and localized within a $30 \mathrm{~km}$ radius around the AERONET sites. To reduce the effect of multiple aerosol scattering, only the collocated data with low AOD are corrected atmospherically [61]. The TANSO-CAI/AERONET collocated data, selected in 2011, with $\tau_{0.55}<0.1$, were obtained from nine global sites (Figure 1 and Table 1) [62]. After atmospheric correction, they were utilized to study the relation between $0.67 \mu \mathrm{m}$ surface reflectance and $1.6 \mu \mathrm{m}$ TOA reflectance.

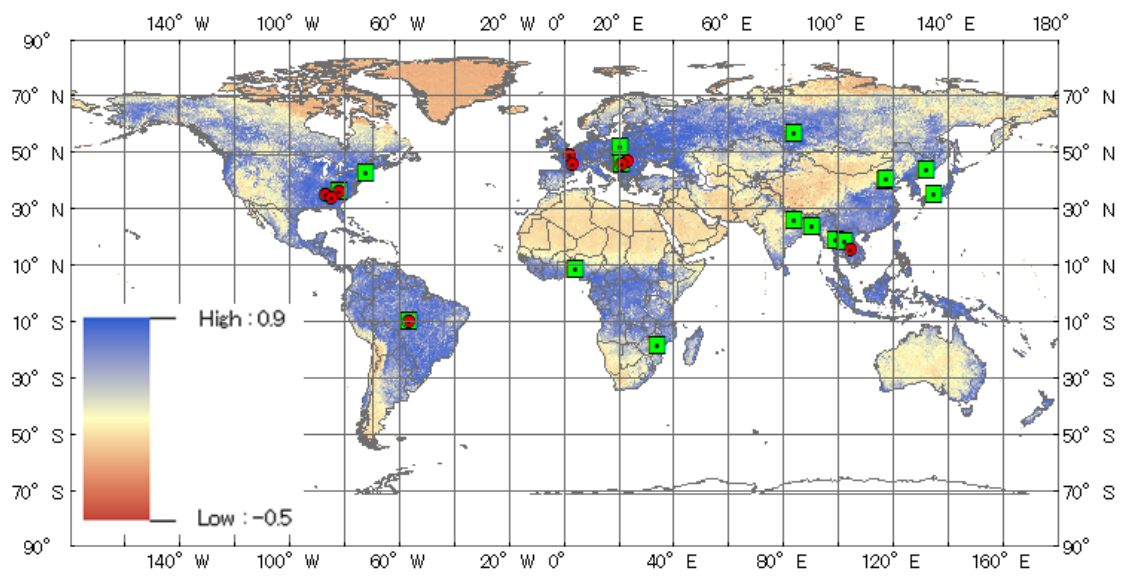

Figure 1. The geographical distribution of AErosol Robotic Network (AERONET) sites (red sites were used for studying reflectance relationships, and green sites were used for validating results) and global Normalized Difference Vegetation Index (NDVI, it ranges from -1 to 1 , a 0 or negative value means no vegetation and close to 1 indicates the highest possible density of green leaves) from TANSO-CAI on 29 June 2015. 
Table 1. The geographical information of AERONET sites $\left({ }^{S}\right.$ sites were used for studying reflectance relationships, $\mathrm{V}$ sites were used for validating results).

\begin{tabular}{|c|c|c|c|}
\hline Site Name & $\begin{array}{c}\text { Longitude } \\
\text { (Decimal_Degrees) }\end{array}$ & $\begin{array}{c}\text { Latitude } \\
\text { (Decimal_Degrees) }\end{array}$ & Elevation (Meters) \\
\hline Alta_Floresta $\mathrm{S}, \mathrm{V}$ & -56.10 & -9.87 & 277 \\
\hline Appalachian_State ${ }^{\mathrm{S}, \mathrm{V}}$ & -81.69 & 36.21 & 1080 \\
\hline Aubiere_LAMP $\mathrm{S}$ & 3.11 & 45.76 & 423 \\
\hline Belsk V & 20.79 & 51.84 & 190 \\
\hline Chiang_Mai_Met_Sta V & 98.97 & 18.77 & 312 \\
\hline CLUJ_UBB S & 23.55 & 46.77 & 405 \\
\hline Dhaka_University V & 90.40 & 23.73 & 34 \\
\hline DRAGON_Mt_Rokko V & 135.23 & 34.76 & 760 \\
\hline Gandhi_College V & 84.13 & 25.87 & 60 \\
\hline Georgia_Tech S & -84.40 & 33.78 & 294 \\
\hline Gorongosa V & 34.35 & -18.98 & 30 \\
\hline Harvard_Forest V & -72.19 & 42.53 & 322 \\
\hline Ilorin V & 4.34 & 8.32 & 350 \\
\hline Palaiseau S & 2.21 & 48.70 & 156 \\
\hline Timisoara $\mathrm{S}, \mathrm{V}$ & 21.23 & 45.75 & 122 \\
\hline Tomsk_22 V & 84.07 & 56.42 & 80 \\
\hline UAHuntsville S & -86.65 & 34.73 & 223 \\
\hline Ubon_Ratchathani $\mathrm{S}$ & 104.87 & 15.25 & 120 \\
\hline Ussuriysk V & 132.16 & 43.70 & 280 \\
\hline Vientiane $^{\mathrm{V}}$ & 102.57 & 17.99 & 170 \\
\hline XiangHe $^{\mathrm{V}}$ & 116.96 & 39.75 & 36 \\
\hline Xinglong $\mathrm{V}$ & 117.58 & 40.40 & 970 \\
\hline
\end{tabular}

\subsection{Relationship between TOA Reflectance at $1.6 \mu \mathrm{m}$ and Surface Reflectance at $0.67 \mu \mathrm{m}$}

Atmospheric correction resulted in surface reflectance at $0.67 \mu \mathrm{m}$ (TANSO-CAI band 2), which was compared with the TOA reflectance at $1.6 \mu \mathrm{m}$; Figure 2a shows a plot of their match-ups and regression line, with the color scale indicating the data frequency. The correlation coefficient $(r)$ value is 0.79 , and the slope and offset are approximately 0.42 and -0.01 . The regression exhibits large scatter and cannot satisfactorily ensure retrieval accuracy. For example, where the TOA reflectance at $1.6 \mu \mathrm{m}$ is 0.2 , the regression function would lead to a surface reflectance of 0.072 at $0.67 \mu \mathrm{m}$. The scatter plot shows the surface reflectance at 0.67 has a large variation, ranging from 0.020 to 0.185 . This uncertainty could cause large deviations in AOD retrieval. Therefore, using this regression function to estimate surface reflectance at $0.67 \mu \mathrm{m}$ is not advised.

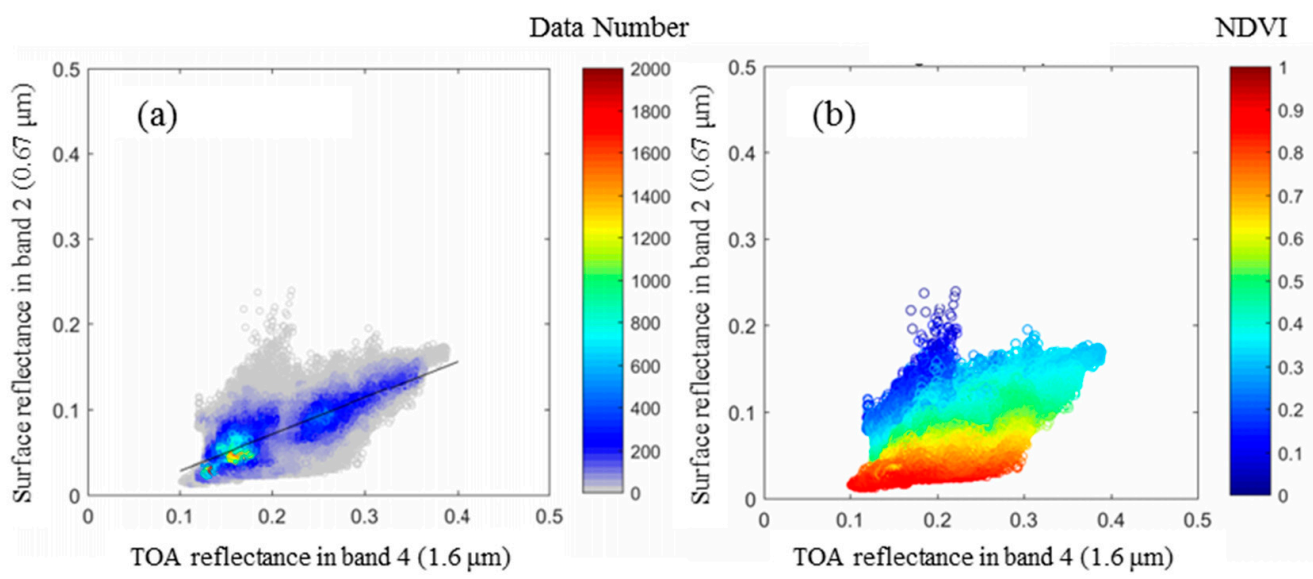

Figure 2. Scatter plots of top-of-atmosphere (TOA) reflectance at $1.6 \mu \mathrm{m}$ and surface reflectance at $0.67 \mu \mathrm{m}$ with: density data frequency (a); and NDVI (b). The results are from TANSO-CAI/AERONET collocated data (selected from the ${ }^{\mathrm{s}}$ marked AERONET sites in Table 1) in 2011 with AOD (at $0.55 \mu \mathrm{m})<0.1$. 
Levy et al. (2007) and Thomas et al. (2008) suggest that the reflectance relationships between the red $(0.67 \mu \mathrm{m})$ and SWIR bands (such as 1.6 and $2.1 \mu \mathrm{m}$ ) vary based on the surface type (vegetation condition/amount) $[23,61,63]$. Figure $2 b$ shows the comparison of the surface reflectance at $0.67 \mu \mathrm{m}$ and TOA reflectance at $1.6 \mu \mathrm{m}$, and the color of each point indicates the value of the NDVI, according to the given color scale. It is easy to see that this relationship of surface reflectance at $0.67 \mu \mathrm{m}$ and TOA reflectance at $1.6 \mu \mathrm{m}(0.67$ vs. 1.6) is a function of NDVI, and an apparent change in regulation is that the higher NDVI data seem to have lower slope, and vice versa. Therefore, like Levy et al. (2007) and Thomas et al. (2008), we also attempted to use the NDVI to indicate the impact of surface variability on the reflectance relationships of the red and SWIR bands $[23,61,63]$. NDVI is a numerical indicator that has been widely applied to estimate the quantity, quality and development of vegetation. It uses the different absorption properties of vegetation toward the red and NIR wavelengths to measure the biomass amount. Sensors onboard satellites or aircrafts can calculate the NDVI value according to Equation (3) [64-66].

$$
\mathrm{NDVI}=\left(\mathrm{R}_{\mathrm{NIR}}-\mathrm{R}_{\mathrm{red}}\right) /\left(\mathrm{R}_{\mathrm{NIR}}+\mathrm{R}_{\mathrm{red}}\right)
$$

where $R_{\text {NIR }}$ and $R_{\text {red }}$ are the reflectances in the NIR and red bands. Specifically, these bands are the TANSO-CAI band $3(0.87 \mu \mathrm{m})$ and band $2(0.67 \mu \mathrm{m})$, respectively. The NDVI values of these experimentally collocated data were calculated performing atmospheric correction on bands 2 and 3 . The scatter plots in Figure 3 are the subsets of the total set of experimental data in Figure 2, they display the reflectance relationships at $1.6 \mu \mathrm{m}$ and $0.67 \mu \mathrm{m}$, varying by intervals of 0.025 in NDVI. Each scatter plot of Figure 3 has a specific 0.67 vs. 1.6 relationship and regression line for a given NDVI value. Almost all of them were found to show significantly higher r-values than the total set of experimental data. In Figure 4, the slopes and intercepts of 0.67 vs. 1.6 regressions (for the scatter plots in Figure 3) are plotted as functions of NDVI. The regression slopes of the scatter plots are highly correlated with NDVI ( $r=-0.955)$, and the slopes are decreasing as surface NDVI increases. In contrast, the regression intercepts have a very weak correlation $(r=-0.198)$ with NDVI changes. Based on these results, an NDVI-dependent regression function for estimating the surface reflectance at $0.67 \mu \mathrm{m}$ from the $1.6 \mu \mathrm{m}$ band was established and is given in Equation (4).

$$
\begin{aligned}
& \mathrm{R}_{0.67}=\text { Slope }_{0.67 / 1.6} * \mathrm{R}_{1.6}+\text { Intercept }_{0.67 / 1.6} \\
& \text { Slope }_{0.67 / 1.6}=\mathrm{a}_{1} * \mathrm{NDVI}+\mathrm{b}_{1} \text {, } \\
& \text { Intercept }_{0.67 / 1.6}=\mathrm{a}_{2} * \mathrm{NDVI}+\mathrm{b}_{2} \text {, }
\end{aligned}
$$

where $R_{0.67}$ is the surface reflectance at $0.67 \mu \mathrm{m} ; R_{1.6}$ is the TOA reflectance at $1.6 \mu \mathrm{m}$; and NDVI is calculated by atmospherically correcting the reflectances of the NIR and red bands. The coefficient values $\left(\mathrm{a}_{1}=-0.605, \mathrm{~b}_{1}=0.590\right.$, and $\left.\mathrm{a}_{2}=-0.009, \mathrm{~b}_{2}=0.023\right)$ are based on the results in Figure 4.

We tested this regression function by comparing the estimated results with the atmospherically corrected surface reflectance using the $6 \mathrm{~S}$ radiative transfer code and AERONET measurements (Figure 5a). With an r-value of 0.959 , the estimated surface reflectance has a very high consistency with the atmospherically corrected surface reflectance. In a biophysical context, as NIR light is reflected by spongy mesophyll cells [66], so it could be expected that higher-density vegetation land surface would show relatively higher reflectance at $0.87 \mu \mathrm{m}$ than other surface types. Many studies suggest that the reflectances of red and SWIR have stronger correlation in dense dark vegetation areas [63]. Therefore, we also tested the data with surface reflectance values higher than 0.25 in band 3 . As depicted in Figure $5 b$, the r-value increases to 0.980 , and most of the overestimated points have been removed. The above results indicate that the relationship of 0.67 vs. 1.6 is dependent on the amount of vegetation and that NDVI can be used as a suitable tuner to interpret how the 0.67 vs. 1.6 ratio changes with different surface types. 


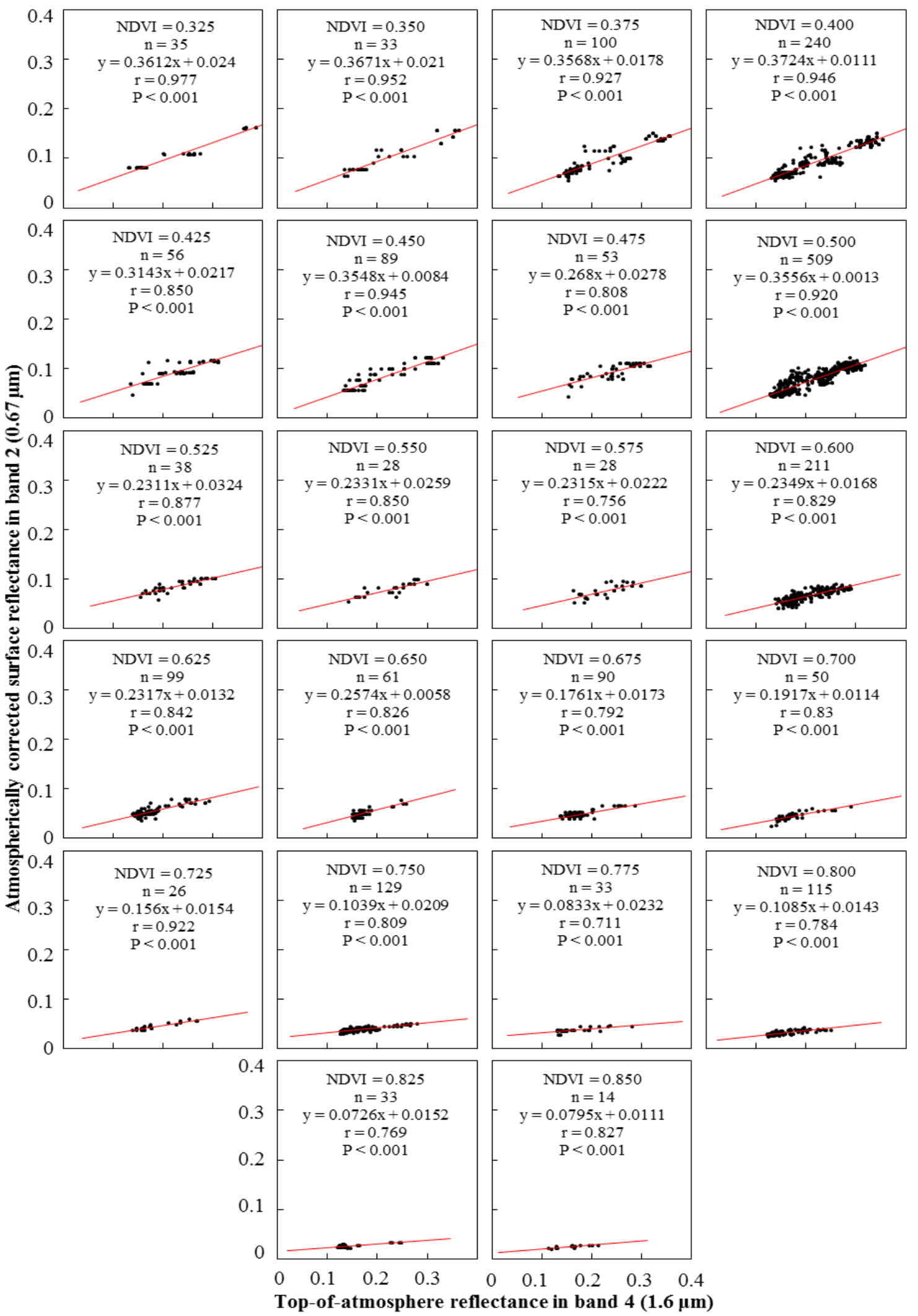

Figure 3. Relationship between TOA reflectances at $1.6 \mu \mathrm{m}$ and surface reflectance at $0.67 \mu \mathrm{m}$ varying with different NDVI values (All data points in each graph fall within NDVI value \pm 0.0001 .). 

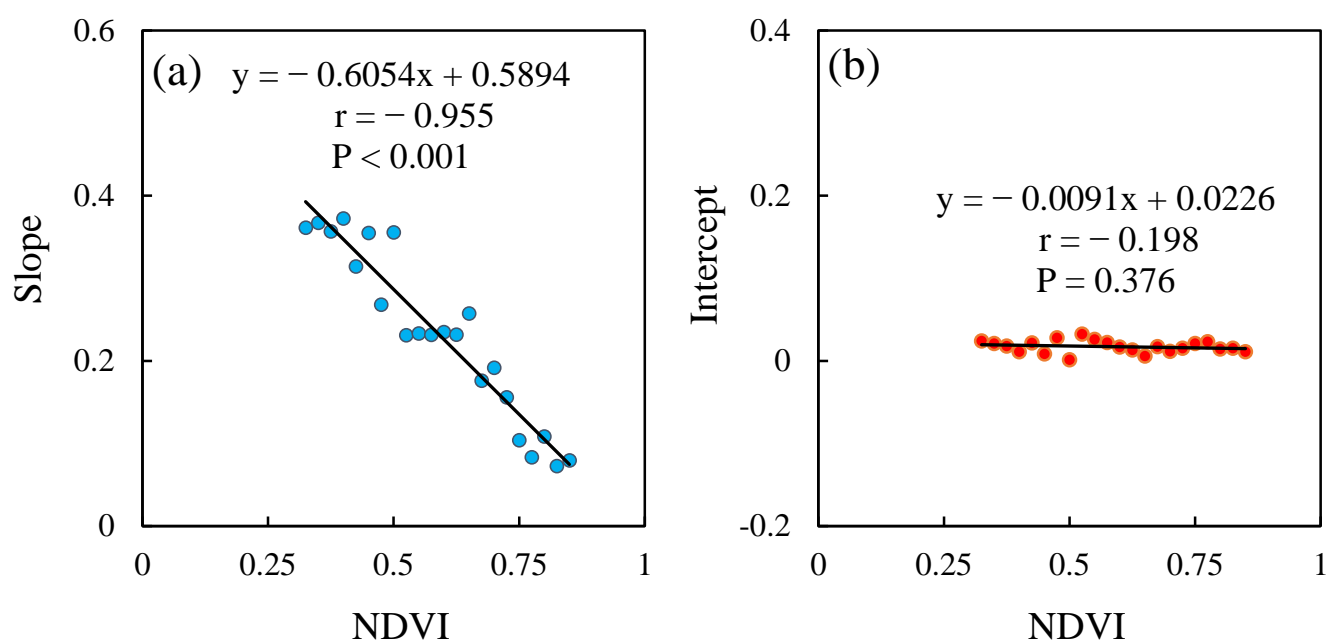

Figure 4. Relationship between TOA reflectances at $1.6 \mu \mathrm{m}$ and surface reflectance at $0.67 \mu \mathrm{m}$ as a function of NDVI: (a) slopes (for each scatter plot in Figure 3 with given NDVI values) as a function of NDVI; and (b) intercepts as a function of NDVI.
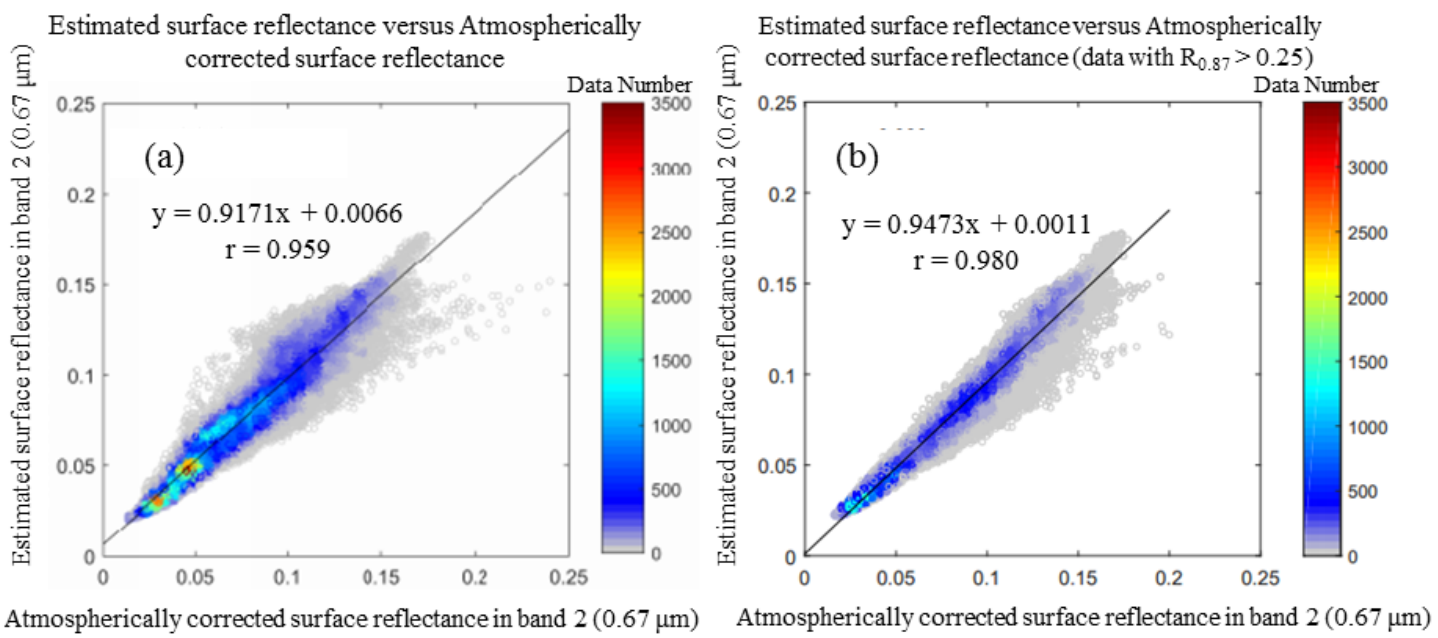

Figure 5. Comparison of estimated surface reflectances and atmospherically corrected surface reflectances at $0.67 \mu \mathrm{m}$ : (a) experimental data; and (b) experimental data with reflectance of band 3 larger than 0.25 .

\subsection{The Modified AFRI $1_{1.6}$ Algorithm}

The NDVI-based regression function has great practicability for estimating surface reflectance under very low aerosol conditions. However, the sensitivity of NDVI to the influence of atmospheric aerosols $[27,28]$ render it ill-suited for estimating reflectance under higher aerosol conditions. Typically, as the AOD increases, the satellite-measured NDVI values rapidly decrease [66,67]. In the MODIS

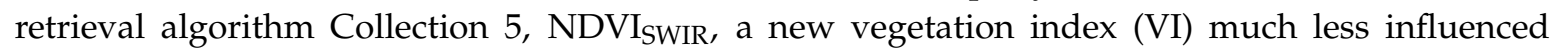
by aerosols, is calculated from the $1.2 \mu \mathrm{m}$ and $2.1 \mu \mathrm{m}$ channels used for estimating the surface conditions [61,63]. Nevertheless, TANSO-CAI does not have the $1.2 \mu \mathrm{m}$ and $2.1 \mu \mathrm{m}$ wavelength bands on board. To overcome these difficulties, we developed a new algorithm based upon the idea of AFRI [68], which was first proposed by Karnieli et al. (2001). AFRI is calculated as function of reflectances of NIR and SWIR (1.6 or $2.1 \mu \mathrm{m})$ bands and described by the following equations.

$$
\mathrm{AFRI}_{2.1}=\left(\mathrm{R}_{\mathrm{NIR}}-0.5 * \mathrm{R}_{2.1}\right) /\left(\mathrm{R}_{\mathrm{NIR}}+0.5 * \mathrm{R}_{2.1}\right)
$$




$$
\mathrm{AFRI}_{1.6}=\left(\mathrm{R}_{\mathrm{NIR}}-0.66 * \mathrm{R}_{1.6}\right) /\left(\mathrm{R}_{\mathrm{NIR}}+0.66 * \mathrm{R}_{1.6}\right)
$$

where $R_{N I R}, R_{1.6}$ and $R_{2.1}$ are the surface reflectances of NIR, 1.6 and $2.1 \mu \mathrm{m}$ bands, respectively, and the coefficients 0.5 and 0.66 are based on the empirical linear relationships between the red $(0.67 \mu \mathrm{m})$ band and the SWIR $(1.6$ and $2.1 \mu \mathrm{m})$ bands that were found by aircraft measurements [68]. The difference between NDVI and AFRI is that the SWIR reflectance has replaced the red reflectance of NDVI, according to these empirical linear relationships. Thus, it takes full advantage of the ability of SWIR to penetrate the atmospheric column containing aerosols with negligible influence; at the same time, it remains sensitive to vegetation and has the potential to become a capable alternative to NDVI for estimating surface status $[68,69]$. AFRI 1.6 and $\mathrm{AFRI}_{2.1}$ were developed based on a single constant linear relationship between red and SWIR bands; however, the relationship of $0.67 \mathrm{vs}$. 1.6 is sensitive to changes in the surface type. Regarding this, it was already shown in Section 3.4 that the relationship of 0.67 vs. 1.6 is typically dependent on surface vegetation conditions (tested using TANSO-CAI bands). Therefore, a single constant linear relationship cannot represent the true correlation of $0.67 \mathrm{vs} .1 .6$ for ground with complicated surface conditions, because any error from a biased linear regression function would be inherited and applied in $\mathrm{AFRI}_{1.6}$.

Combining the main strategies of the AFRI and the NDVI-based regression functions, we developed a new aerosol-free NDVI estimation method named the modified AFRI ${ }_{1.6}$ algorithm. The modified AFRI 1.6 algorithm retains the original advantages of AFRI ${ }_{1.6}$, which is less influenced by aerosols, but replaces the single constant relationship-based method with a method that takes the vegetation-dependent relationships of 0.67 vs. 1.6 into account. Equation (4) can be rewritten as Equation (7), in which, the surface reflectance at $0.67 \mu \mathrm{m}$ is a function of both the NDVI and TOA surface reflectance at $1.6 \mu \mathrm{m}$. Equation (8) shows the NDVI calculated from the TANSO-CAI bands.

$$
\begin{gathered}
\mathrm{R}_{0.67}=\left(\mathrm{a}_{1} * \mathrm{NDVI}+\mathrm{b}_{1}\right) * \mathrm{R}_{1.6}+\mathrm{a}_{2} * \mathrm{NDVI}+\mathrm{b}_{2} \\
\mathrm{NDVI}=\left(\mathrm{R}_{0.87}-\mathrm{R}_{0.67}\right) /\left(\mathrm{R}_{0.87}-\mathrm{R}_{0.67}\right)
\end{gathered}
$$

where $\mathrm{R}_{0.87}$ is the TOA reflectance of TANSO-CAI band 3; $\mathrm{R}_{0.67}$ is the estimated surface reflectance of TANSO-CAI band 2; and NDVI is the aerosol-free NDVI, calculated by $\mathrm{R}_{0.87}$ and $\mathrm{R}_{0.67}$. By substituting Equation (7) into Equation (8), and then rearranging, we obtain Equation (9).

$$
\begin{gathered}
\operatorname{NDVI}^{2} *\left(\mathrm{a}_{1} * \mathrm{R}_{1.6}+\mathrm{a}_{2}\right)+\mathrm{NDVI} *\left(\mathrm{R}_{0.87}+\left(\mathrm{a}_{1}+\mathrm{b}_{1}\right) * \mathrm{R}_{1.6}+\mathrm{a}_{2}+\mathrm{b}_{2}\right) \\
+\left(\mathrm{b}_{1} * \mathrm{R}_{1.6}+\mathrm{b}_{2}-\mathrm{R}_{0.87}\right)=0
\end{gathered}
$$

Equation (9) is a quadratic equation in NDVI, and the solutions of the equation are as follows:

$$
\text { NDVI }=\frac{-\left(\mathrm{R}_{0.87}+\left(\mathrm{a}_{1}+\mathrm{b}_{1}\right) * \mathrm{R}_{1.6}+\mathrm{a}_{2}+\mathrm{b}_{2}\right) \pm \sqrt{\left(\mathrm{R}_{0.87}+\left(\mathrm{a}_{1}+\mathrm{b}_{1}\right) * \mathrm{R}_{1.6}+\mathrm{a}_{2}+\mathrm{b}_{2}\right)^{2}-4 *\left(\mathrm{a}_{1} * \mathrm{R}_{1.6}+\mathrm{a}_{2}\right) *\left(\mathrm{~b}_{1} * \mathrm{R}_{1.6}+\mathrm{b}_{2}-\mathrm{R}_{0.87}\right)}}{2 *\left(\mathrm{a}_{1} * \mathrm{R}_{1.6}+\mathrm{a}_{2}\right)}
$$

In Equations (7)-(10), the coefficient values are $\mathrm{a}_{1}=-0.605, \mathrm{~b}_{1}=0.590$, and $\mathrm{a}_{2}=0, \mathrm{~b}_{2}=0.023$. Among these, $\mathrm{a}_{2}$ was set to a value of 0 since the relationship of the intercepts with NDVI is considered very weak. As Equation (10) shows, this formula has two roots. In actual retrieval, only one reasonable root would be obtained because NDVI should be within the range of -1 to 1 and the other root exceeds this range. Using the estimated aerosol-free NDVI in Equation (7), the surface reflectance at $0.67 \mu \mathrm{m}$ can be estimated and used to retrieve the AOD.

\subsection{The Look-Up Table}

The AOD can be determined by solving the radiative transfer equation with the relevant atmospheric parameters. For faster processing, we created a look-up table using the $6 \mathrm{~S}$ radiative transfer code that has been widely used in different remote-sensing applications and sensors; for example, it is used to calculate the look-up table for MODIS atmospheric correction algorithm [61,70]. This look-up table includes pre-computed atmospheric parameters $\left(R_{P a t h}, T_{d} T_{u}\right.$ and $\left.S\right)$ with given 
combinations of aerosol models, geometrical conditions and AODs. By using the look-up table, the appropriate atmospheric parameter combinations for solving the radiative transfer equation, can be rapidly selected, thereby improving retrieval efficiency.

The $6 \mathrm{~S}$ model is applicable for calculating atmospheric radiative transfer with a solar reflection range of 0.25 to $4.0 \mu \mathrm{m}$, and a $2.5 \mathrm{~nm}$ step used for spectral integration [61]. Before using the $6 \mathrm{~S}$ model, the spectral condition of GOSAT TANSO-CAI was defined band by band with the interpolated TANSO-CAI Spectral Response Function. The look-up table was constructed using the following parameters: geometrical conditions, atmosphere model, aerosol models, AOD and atmospheric parameters $\left(R_{\text {Path }}, T_{d} T_{u}\right.$ and $\left.S\right)$. The geometrical conditions include twenty-one solar zenith angles from $0^{\circ}$ to $60^{\circ}$ with a step of $3^{\circ}$, six satellite zenith angles from $0^{\circ}$ to $60^{\circ}$ with a step of $12^{\circ}$, eight relative azimuth angles from $0^{\circ}$ to $168^{\circ}$ with a step of $24^{\circ}$, and one relative azimuth angle at $180^{\circ}$. Three different atmosphere models, Tropical, Midlatitude Summer and Midlatitude Winter, were taken into account. Because the previous atmospheric correction was performed with the continental aerosol model, we selected the continental aerosol model as the aerosol model for the look-up table construction $[16,61]$. AOD values in the look-up table were set: the smallest with a value of 0.001 , and others in the range of 0.01 to 2.00 with an increment of 0.01 .

\subsection{AOD Retrieval}

In this paper we use the TANSO-CAI $1.6 \mu \mathrm{m}$ band to estimate the surface reflectance of $0.67 \mu \mathrm{m}$ band to retrieve the AOD. According to the observation geometry parameters (solar zenith angle, azimuth angle, satellite zenith angle, and azimuth angle) in the satellite data files, the relevant observation geometry parameters that are equal or closest to the values in the established look-up table can be selected. Corresponding to the selected geometric parameters, there are multiple sets of $\mathrm{R}_{\text {Path }}$ $T_{d} T_{u}$ and $S$ values with different $A O D$ values. We input every parameter set and the surface reflectance into Equation (1) to calculate the theoretical apparent reflectance in the $0.67 \mu \mathrm{m}$ band. Then we could obtain multiple sets of theoretical apparent reflectances. Comparing the apparent reflectance of the TANSO-CAI data with these theoretical apparent reflectances, the one closest to the actual apparent reflectance and its corresponding AOD was selected as the retrieved AOD of this pixel.

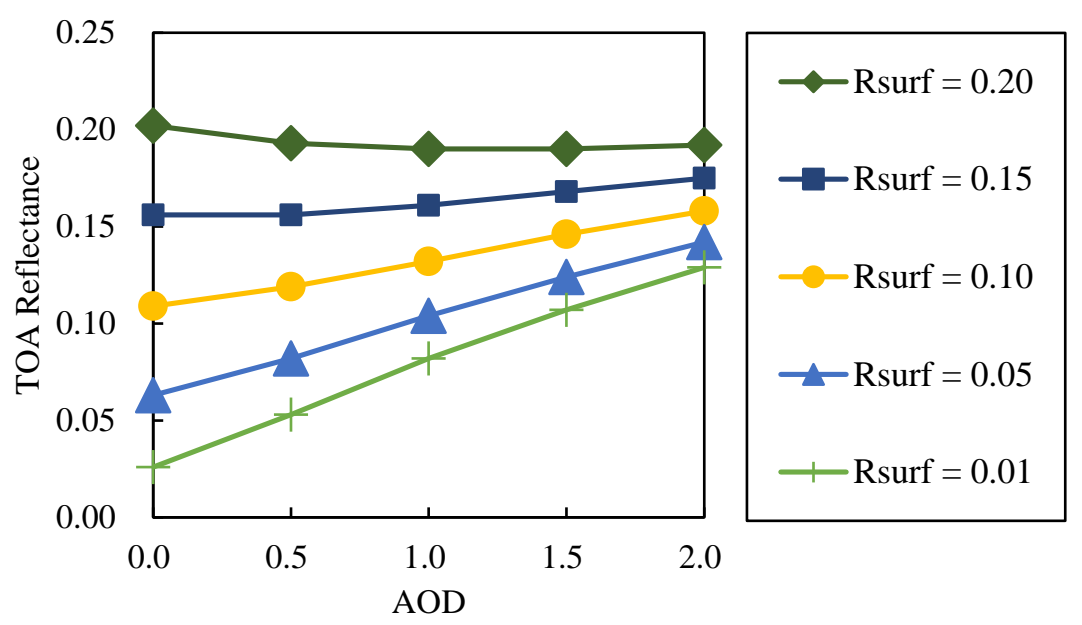

Figure 6. TOA reflectance as a function of AOD and surface reflectance at $0.67 \mu \mathrm{m}$. Simulation is performed under the observation geometric conditions with solar zenith angle $=45^{\circ}$, satellite zenith angle $=2^{\circ}$ and relative azimuth angles $=45^{\circ}$.

However, due to the limitations of the instruments and algorithm, not all pixels can be used for retrieval. For example, when using the DT algorithm, the dark pixels should be preselected. We simulated the relationship between the TOA reflectance in the TANSO-CAI $0.67 \mu \mathrm{m}$ band and the AOD for different surface reflectances using the $6 \mathrm{~S}$ code. Figure 6 demonstrates that the higher 
surface reflectance has smaller TOA reflectance changes as AOD increases. Namely, the higher surface reflectance areas are not sensitive to the AOD changes. It is noted that when the surface reflectance increases from 0.01 to 0.1 , the TOA reflectance still responds to the increase in the AOD. To reduce the simulation difference, even with other observed geometric conditions, the pixels with surface reflectance values that are higher than 0.085 should not be selected to perform AOD retrieval [23]. In addition, based on the results presented in Section 3.4, to ensure the AOD retrieval accuracy, the thresholds of TOA reflectance of red band and estimated aerosol-free NDVI were set, when the TOA reflectance of red band is lower than 0.225 , or the estimated aerosol-free NDVI is out the range of 0.375 to 0.825 , it should not be taken into account during the retrieval.

\section{Results and Discussion}

\subsection{Case Study over South Asia}

An example of the AOD retrieval over the South Asian region from TANSO-CAI using our algorithm is shown in Figure 7. Figure 7a,b shows the TANSO-CAI RGB composite images (shown in true color) of 4 and 7 November 2011, and their retrieved AOD distributions are shown in Figure 7c,d, respectively. The Southwestern part of China, Nepal and the Northern part of India are covered in this scene. The area between lines A and B is the North of Indo-Gangetic basin, one of the world's largest drainage basins [71]. It is bordered by the Himalayas, which are located on the border between Nepal and Tibet, China. Rapidly growing industrialization and expanding urbanization has led to high pollution in these regions, and as such it has become a regional aerosol hot spot [71,72]. Comparing Figure 7a,b, the air condition of Figure 7a in the region between lines A and B seems highly polluted. This could be attributed to the burning of biomass. We used MODIS Thermal Anomalies/Fire products (MOD14A1) [73] to detect the occurrence of fire. A large patch of clustered burning spots out of and near the scene was extracted on 4 November 2011, and burning spots were apparently decreased on 7 November 2011. As shown in Figure 7c,d, the relatively higher AOD dominates in the area between lines A and B; in contrast, very low AOD is distributed in the area between lines B and C. This is due to the unique topography (Figure 7e), with the mighty Himalayan peaks [74] of acting like a barrier and blocking the transfer of biomass-burning aerosols, causing the aerosols to accumulate in the area between lines A and B surrounding the peaks. Our retrieval result successfully illustrated the contrast in AOD between areas of $\mathrm{AB}$ (line $\mathrm{A}$ to line $\mathrm{B}$ ) and $\mathrm{BC}$ (line $\mathrm{B}$ to line $\mathrm{C}$ ). Additionally, as the terrain gradually increases from the foot of a hill to the top (near the area of line B), the influx of aerosols decreases and becomes rare. Our results also reflected this detailed gradual change in AOD: over the area of the peak slope, there is a long and narrow zone with smoothly changing color. We can see that there is only a small retrieval result in the China area (the area north of line $\mathrm{C}$ ). This is mainly because the surface over western China is relatively bright [26], and when the estimated surface reflectance is higher than 0.085, those pixels are not taken into account in the AOD retrieval. The absence of AOD retrieval in the area between lines A and B is also caused by the high estimated surface reflectance and the influence of cloud cover. The AERONET station Pokhara, located in the southeastern part of the image, provided the AOD measurements within $\pm 15 \mathrm{~min}$ of the satellite observation time, and the mean AOD on 4 and 7 November are 1.98 and 0.57, respectively. The results of our algorithm show that the retrieved AOD near the Pokhara station are 1.95 and 0.65 on corresponding date, very close to the AERONET measurements. The details of validation using ground-level measurements from global sites are shown in Section 4.2. As shown in this case study, one of the deficiencies as well as challenges in the retrieval performance is that there are some retrieved spots at the edges of clouds. 

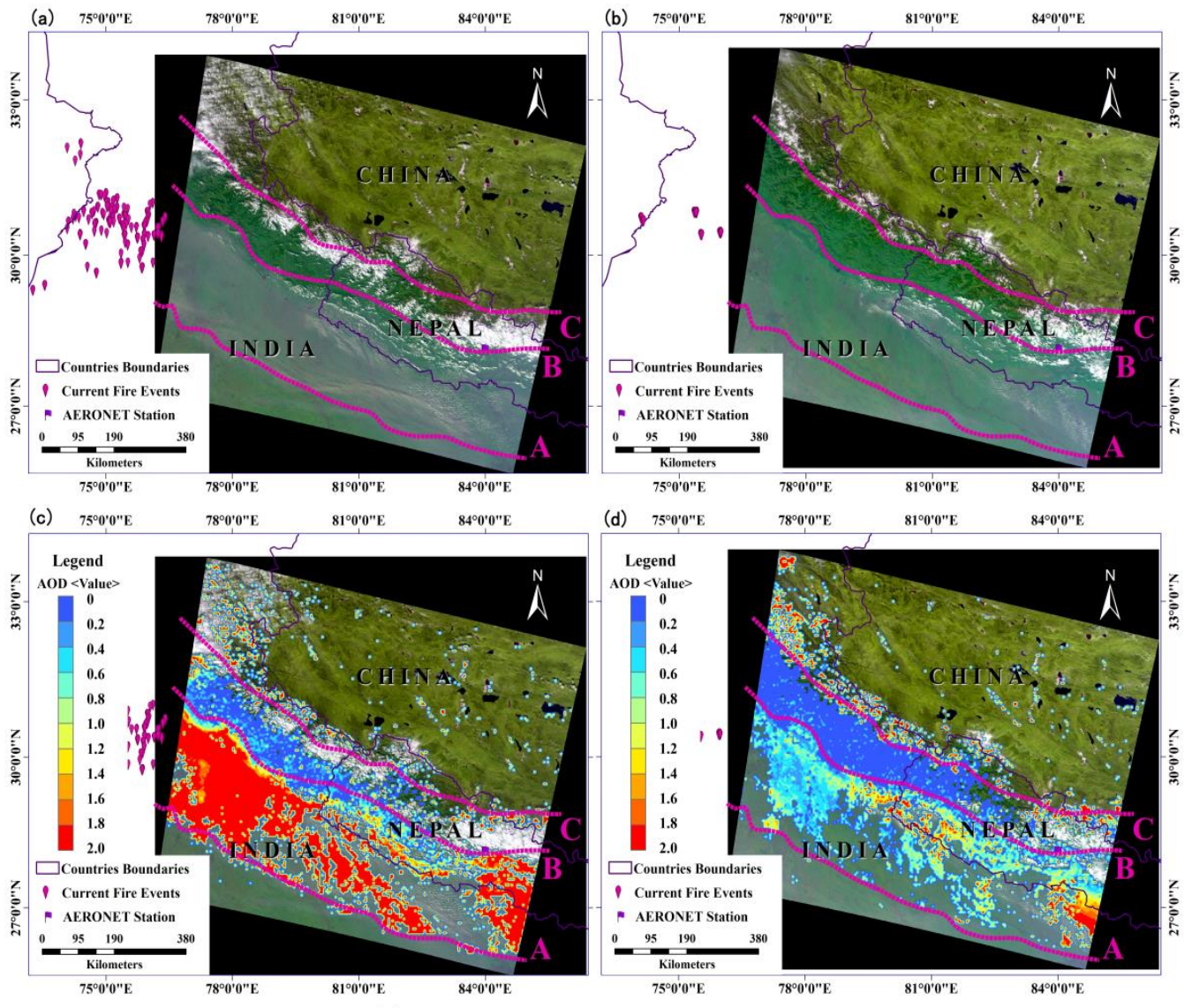

(d) $75^{\circ} 0^{\prime} 0$

${ }^{78} 8^{\circ} 0^{\circ} 0^{\prime \prime E} \quad 81^{\circ} 0^{\circ} 0^{\prime \prime} \mathrm{E} \quad 84^{\circ} 0^{\circ} 0^{\prime \prime E}$
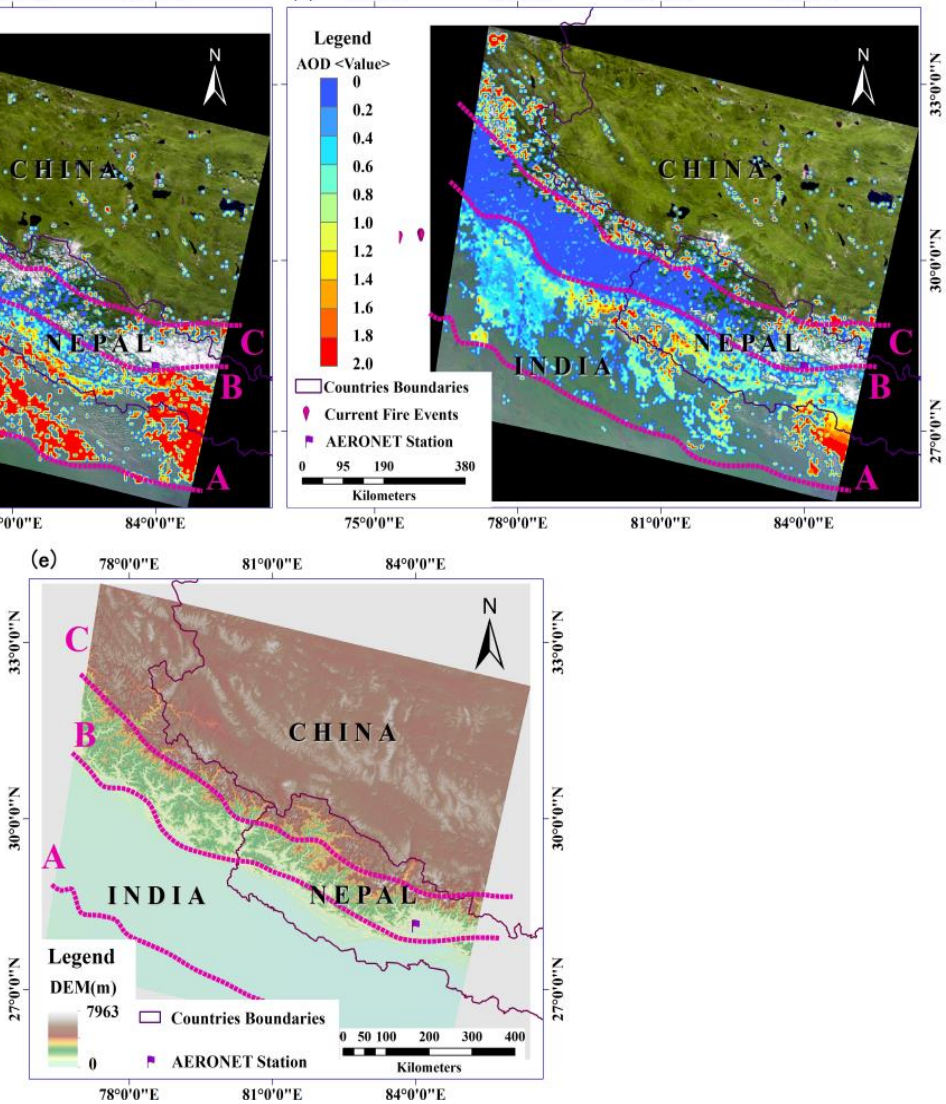

Figure 7. Examples of the AOD retrieval over South Asian region: (a) RGB image from TANSO-CAI on 4 November 2011; (b) RGB image from TANSO-CAI on 7 November 2011; (c) retrieved AOD at $550 \mathrm{~nm}$ on 4 November 2011; (d) retrieved AOD at $550 \mathrm{~nm}$ on 7 November 2011; and (e) topographic image.

\subsection{Comparison of Retrieved AOD with AERONET Measurements}

For quantitative validation, ground-based Sun photometer measurements are widely used to evaluate the accuracy of AOD satellite retrievals. All ground-based AOD measurements from AERONET that are within $15 \mathrm{~min}$ of the GOSAT observation are considered for validation. The TANSO-CAI/AERONET collocation criteria [75-77] for validation are more stringent in space. AOD results retrieved within a radius of $7.5 \mathrm{~km}$ of the AERONET site are averaged and then evaluated by comparison with a total of 300 collocated data points, provided from 16 AERONET sites for the period from April 2009 to August 2014. The 16 AERONET sites are located in East Asia (XiangHe, DRAGON_Mt_Rokko and XiangHe), Southeast Asia (Chiang_Mai_Met_Sta, Vientiane and 
Gandhi_College), South Asia (Dhaka_University), North Asia (Tomsk_22 and Ussuriysk), South Africa (Gorongosa and Ilorin), Europe (Belsk and Timisoara), South America (Alta_Floresta) and North America (Appalachian_State and Harvard_Forest) (green points in Figure 1).

The scatter plots of TANSO-CAI versus AERONET AOD are shown in Figure 8. The linear regression analysis shows that the TANSO-CAI-retrieved AOD has high agreement on the AERONET AOD with an r-value of 0.91 . The regression line lies close to the one-to-one line with a slope of 1.10 and an intercept of 0.02 . In addition to the linear regression analysis, some additional statistical indicators, including root mean square error (RMSE), mean bias error (MBE) and expected error (EE), were used to evaluate this algorithm. The RMSE $[50,78,79]$ is sensitive to systematic and random errors. It is an absolute criterion and is commonly used to determine differences between satellite-retrieved AODs and ground-measured AODs. The RMSE (Equation (11)) is defined as follows.

$$
\operatorname{RMSE}=\sqrt{\frac{1}{n} \sum_{i}^{n}\left(A O D_{(T A N S O-C A I) i}-A O D_{(A E R O N E T) i}\right)^{2}} .
$$
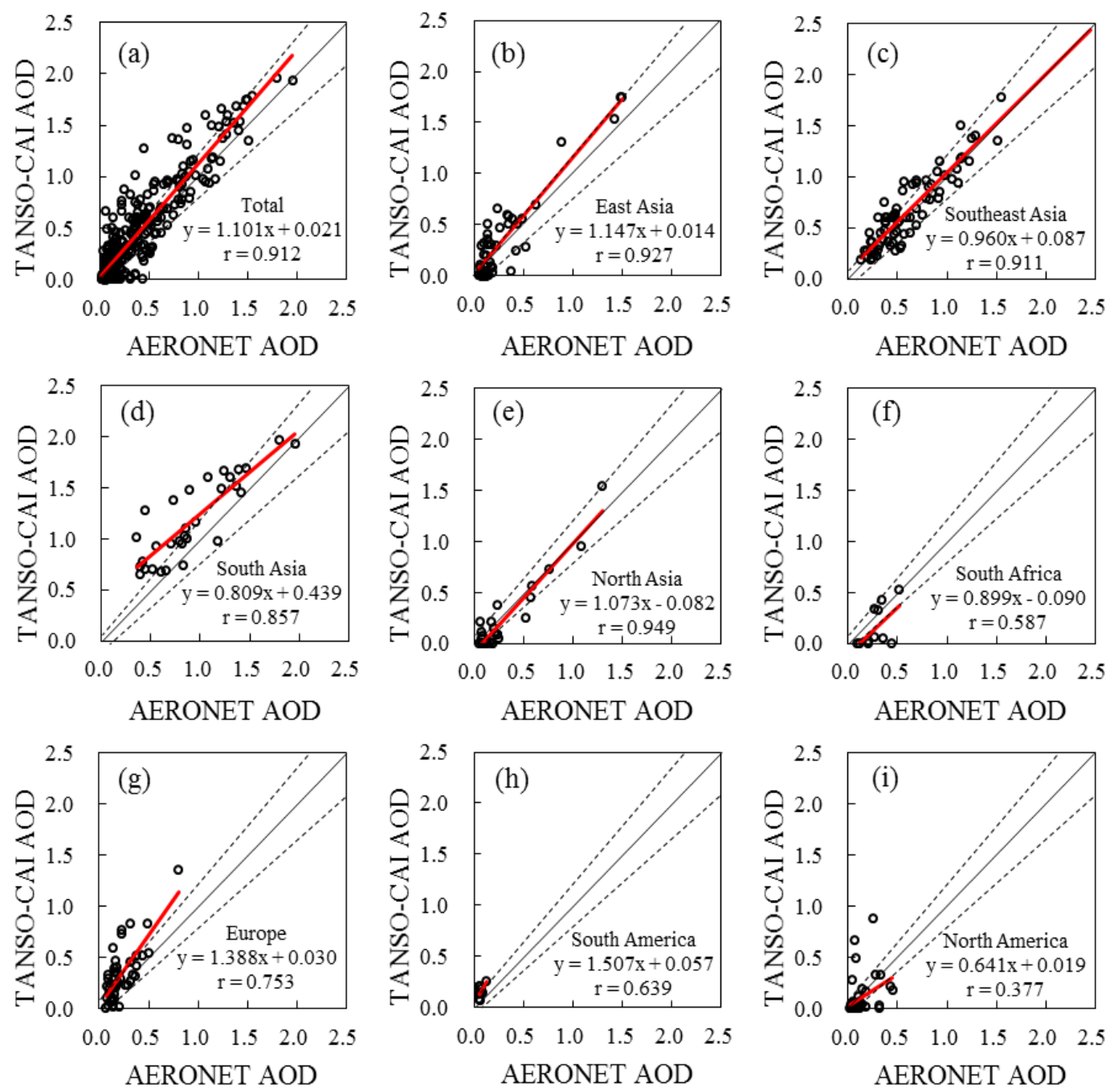

Figure 8. The comparison of retrieved AOD and AERONET measurements over different regions: (a) all regions; (b) East Asia; (c) Southeast Asia; (d) South Asia; (e) North Asia; (f) South Africa; (g) Europe; (h) South America; and (i) North America. The red solid, black solid and dashed lines are the regression line, one-to-one line and expected error $(\mathrm{EE} 1)\left( \pm 0.05 \pm 0.15 \mathrm{AOD}_{(\mathrm{AERONET})}\right)$ envelope line, respectively. 
The MBE [80] (Equation (12)) is used here to measure the mean error magnitude and calculated as

$$
\mathrm{MBE}=\frac{1}{n} \sum_{i}^{n}\left(A O D_{(T A N S O-C A I) i}-A O D_{(A E R O N E T) i}\right) .
$$

EE [81] can denote the expected uncertainty of retrieval and is the major target of the validation studies. It is a confidence envelope that encompasses the sum of the absolute (dominating at low AOD) and relative (dominating at high AOD) AOD errors. The definition of EE (Equation (13)) is based on a single criterion: at least 66\% (approximately one standard deviation) of the collocated AOD match-ups fall within the corresponding envelope that is described as

$$
A O D_{(A E R O N E T)}-|E E| \leq A O D_{(T A N S O-C A I)} \leq A O D_{(A E R O N E T)}+|E E| .
$$

Many studies have estimated the uncertainties of satellite-retrieved AOD and attempted to define EE to validate a related algorithm or product [81]. Prior to the Terra launch, Kaufman et al. (1997) estimated the EE $\left( \pm 0.05 \pm 0.2 \mathrm{AOD}_{\text {(AERONET) }}\right)$ of MODIS-retrieved AOD by sensitivity studies [17]. After the launch of Terra (later renamed Aqua), Chu et al. (2002) estimated the MODIS-measured AOD with the EE $\left( \pm 0.05 \pm 0.2 \mathrm{AOD}_{(\mathrm{AERONET})}\right)$ [82]. MODIS Collection 5 (C005) DT aerosol products is reported EE for land to $\pm 0.05 \pm 0.15 \mathrm{AOD}_{\text {(AERONET) }}$ [83]. In addition, Mei et al. (2014) defined EE with a different envelope of $\pm 0.1 \pm 0.15 \mathrm{AOD}_{\text {(AERONET) }}$ for an AVHRR retrieval algorithm [26]. We tried three different EEs (EE1: $\pm 0.05 \pm 0.15 \mathrm{AOD}_{(\mathrm{AERONET})}, \mathrm{EE2}: \pm 0.05 \pm 0.2 \mathrm{AOD}_{(\mathrm{AERONET})}, \mathrm{EE} 3: \pm 0.10$ $\left.\pm 0.15 \mathrm{AOD}_{(\mathrm{AERONET})}\right)$ mentioned above to estimate $\mathrm{AOD}$ retrieval uncertainty. The analysis of the results of our algorithm (for total retrieval) shows that the RMSE and MBE between the TANSO-CAI and AERONET AOD are 0.196 and 0.052. The proportion of retrievals agreeing within EE1 of the AERONET measurements is $48.0 \%$. For the relaxed criteria with EE3, there are $67.7 \%$ match-ups within the EE3.

Although a good level of agreement was found for the total set of retrieved AOD from the globally distributed sites, we had no idea how the algorithm would behave over different regions [84]. To study more detailed situations than the descriptions for the total data in Figure 8a, it is instructive to regionally compare the TANSO-CAI and AERONET according to the locations of the AERONET sites. Based on the previous analysis methods, the following statistics are shown in the Table 2: number of experimental points $(\mathrm{N})$, regression line, correlation coefficient (r), RMSE (AOD unit), MBE and EEs (EE1, EE2 and EE3) for each region (East Asia, Southeast Asia, South Asia, North Asia, South Africa, Europe, South America and North America). The comparisons of TANSO-CAI versus AERONET AOD for each region are shown in Figure 8b-i. For all regions except South Asia, which has a high ground-truth AOD, the RMSE and the MBE are always below 0.22 and 0.12, respectively (in absolute terms). The TANSO-CAI AOD obtained very high r-value (more than 0.85) in East Asia, Southeast Asia, South Asia and North Asia. Among them, South Asia has the poorest RMSE and MBE in all regions. The proportions of the points within EEs are only with $35.5 \%, 54.8 \%$ and $51.6 \%$ for EE1, EE2 and EE3, respectively. This could be explained by the complicated surface-cover types around the Dhaka_University AERONET site, which lead to improper estimations of surface reflectance during certain seasons, because for two consecutive years we found that most of the outliers were obtained during the period from February to April. On the other hand, the high ground-truth AOD (with a mean value of 0.915 ) can also bring uncertainties due to the effect of multiple scattering. Contrary to South Asia, the results for North America show a low r-value of 0.377 , but a large proportion of data within EEs. As shown in Figure 8i, the ground-truth AOD was very low (with a mean value of 0.102). The retrieval errors and the insufficient observation of high AOD experimental data lead to the low statistical r-value; however, the low RMSE and MBE (in absolute terms), and the match-up rate of $66 \%$ within EE1 indicate that our algorithm achieved good performance in North America. 
Table 2. Summary statistics for the entire dataset and each individual region: number of samples (N), correlation coefficients (r), RMSE, MBE and EEs.

\begin{tabular}{ccccccccc}
\hline Region & N & Mean AERONET AOD & $\mathbf{r}$ & RMSE & MBE & EE1 & EE2 & EE3 \\
\hline East Asia & 49 & 0.282 & 0.927 & 0.178 & 0.055 & $36.7 \%$ & $38.8 \%$ & $59.2 \%$ \\
Southeast Asia & 76 & 0.646 & 0.911 & 0.159 & 0.018 & $56.6 \%$ & $65.8 \%$ & $77.6 \%$ \\
South Asia & 31 & 0.915 & 0.857 & 0.343 & 0.264 & $35.5 \%$ & $54.8 \%$ & $51.6 \%$ \\
North Asia & 26 & 0.307 & 0.949 & 0.129 & -0.073 & $38.5 \%$ & $42.3 \%$ & $61.5 \%$ \\
South Africa & 11 & 0.283 & 0.578 & 0.167 & -0.119 & $9.1 \%$ & $36.4 \%$ & $54.5 \%$ \\
Europe & 45 & 0.217 & 0.753 & 0.213 & 0.114 & $46.7 \%$ & $51.1 \%$ & $60.0 \%$ \\
South America & 9 & 0.067 & 0.639 & 0.102 & 0.091 & $33.3 \%$ & $33.3 \%$ & $66.7 \%$ \\
North America & 53 & 0.102 & 0.377 & 0.164 & -0.018 & $66.0 \%$ & $71.7 \%$ & $83.0 \%$ \\
Total & 300 & 0.381 & 0.912 & 0.196 & 0.052 & $48.0 \%$ & $55.0 \%$ & $67.7 \%$ \\
\hline
\end{tabular}

Although the mean ground-truth AOD in Southeast Asia were measured with a high value of 0.646, good retrieval is still observed over this region with low RMSE and MBE, high r-value, a large proportion of experimental data within EEs, and a regression line that is very close to the one-to-one line. This is not surprising as the Chiang_Mai_Met_Sta, Vientiane and Gandhi_College AERONET sites are typical rural vegetated sites, which have relatively lower surface reflectances and are ideal for AOD retrieval [85]. The experimental data for Europe are from the Belsk and Timisoara sites. The Belsk site is a vegetated rural site, and the Timisoara site is located in the center of one of the most developed towns in Romania [86]. It can clearly be seen in Figure 8g that the retrieved AOD for this region is easily overestimated, compared with the ground-level measured data. In the analysis, we found that almost all the outliers with large errors are from Timisoara. It is possible that uncertainty arises from the complicated reflectance relationship between the $0.67 \mathrm{vs}$. 1.6 over urban areas and high local emissions, such as aerosol pollution from roads and power plants $[85,86]$, both of which pose a huge challenge to the satellite retrieval of aerosol properties.

The sites in North Asia, South Africa and North America all have negative MBE values $(-0.073$, -0.119 and -0.018 , respectively). We found that the AERONET sites in these regions, which have very high vegetation backgrounds, tend to underestimate AOD in very light loading conditions. Similarly, the MODIS DT algorithm also tends to underestimate dark-target sites with small AOD $[81,87]$. This error may result from the systematic overestimation of the surface reflectance, since the parameters in the regression function for estimating surface reflectance are determined by the experimental data over the selected areas (in Section 3), and high-quality estimations are concentrated on a certain range of surface-type variation. When the algorithm is applied to an extremely highly vegetated or bare-surface area, the factual parameters for estimating surface reflectance would be biased toward the parameters presumed by these overall experimental data, and the biases would become intrinsic systematic errors [87].

Only two regions (Southeast Asia and North America) had more than $55 \%$ of match-ups fall in EE1. Even excluding the two regions (South Africa and South America) that have very small volumes of collocated data, only $35.5 \% \sim 46.7 \%$ of match-ups fell in EE1 for the other regions. Obviously, EE1 is an overly strict criterion with which to evaluate the accuracy of the current algorithm. For the relaxed EEs, at least $51 \%$ of match-ups fell into EE3 for each region. Comparing the results for EE2 and EE3, more match-ups were virtually contained in EE3 for all regions (except for South Asia). The statistics in Table 3 show that the proportions of match-ups that fell well within EEs are higher for the observations with higher ground-truth AOD [16], and most of the match-ups that fell below the EEs were for lower aerosol loading conditions. 
Table 3. Proportions of match-ups below, within and above the EEs for AOD $<0.6$ and $>0.6$.

\begin{tabular}{ccccccccccc}
\hline \multirow{2}{*}{ AODs } & \multirow{2}{*}{$\mathbf{N}$} & \multicolumn{3}{c}{ EE1 } & \multicolumn{3}{c}{ EE2 } & \multicolumn{3}{c}{ EE3 } \\
\cline { 3 - 11 } & & Below & Within & Above & Below & Within & Above & Below & Within & Above \\
\hline AOD $<\mathbf{0 . 6}$ & 238 & $23.1 \%$ & $44.5 \%$ & $32.4 \%$ & $21.0 \%$ & $48.3 \%$ & $30.7 \%$ & $12.2 \%$ & $64.7 \%$ & $23.1 \%$ \\
AOD $>\mathbf{0 . 6}$ & 62 & $3.2 \%$ & $61.3 \%$ & $33.9 \%$ & $0 \%$ & $80.6 \%$ & $19.4 \%$ & $0 \%$ & $79.0 \%$ & $20.9 \%$ \\
\hline
\end{tabular}

\section{Conclusions}

We introduced a new aerosol retrieval algorithm for land from the observation of the GOSAT TANSO-CAI sensor. Based upon the preliminary analysis from selected TANSO-CAI/AERONET collocations, we found that the relationship between surface reflectance in the red band and TOA reflectance in the SWIR $1.6 \mu \mathrm{m}$ band varies with surface conditions. The NDVI was successfully utilized as a key factor to interpret the variety of $0.67 \mathrm{vs}$. 1.6 ratios with different surface properties. A regression function dependent on NDVI to estimate the surface reflectance of red band from the TOA reflectance of the $1.6 \mu \mathrm{m}$ band for clear-sky conditions (AOD at $0.55 \mu \mathrm{m}$ less than 0.1 ) was summarized. We compared the estimated surface reflectance against the atmospherically corrected surface reflectance, and the results show that the estimated surface reflectance has a very good agreement with the theoretical surface reflectance. The results also confirmed that the correlations between the $0.67 \mathrm{vs} .1 .6$ are vegetation dependent and proved that the regression function is practical and accurate for this application. The main problem in aerosol retrieval is that the NDVI itself can be affected by aerosols. Therefore, by combining the advantages of AFRI, which can resist the influences from atmospheric aerosols, with our regression function, which can preserve the correlations of $0.67 \mathrm{vs} .1 .6$ with different vegetation amounts, a modified $\mathrm{AFRI}_{1.6}$ algorithm for estimating aerosol-free NDVI and surface reflectance of $0.67 \mu \mathrm{m}$ was developed. This modified $\mathrm{AFRI}_{1.6}$ algorithm-based AOD retrieval was tested by comparing its results with the collocated AERONET AOD from 16 AERONET sites located in different global regions. The results show that the retrieved AOD has very high consistency with the AERONET measurements, with an r-value of 0.912, and a regression line (with an equation of $y=1.101 x+0.021)$ that lies close to the one-to-one line. There are $67.7 \%$ experimental match-ups falling within the $\mathrm{EE}$ of $\pm 0.1 \pm 0.15 \mathrm{AOD}_{\text {(AERONET) }}$. Due to fewer spectral bands being available in GOSAT TANSO-CAI, only one visible band was used for aerosol retrieval, and its accuracy and ability has been limited. Because the single-band retrieval algorithm does not have the degree of freedom to choose aerosol type [88], the current algorithm used the continental aerosol model to describe the aerosol condition. Although the continental aerosol model is an often used assumption over land surfaces, it is obviously not satisfactory for all aerosols conditions. Improperly assuming aerosol type can lead to errors in retrieval. In addition, as a typical vegetation-dependent algorithm (similar with MODIS DT algorithm Collection 5), this algorithm does not aim to work for bright surface (e.g., desert or urban).

This algorithm demonstrates a new approach to retrieve AOD from an onboard satellite sensor that can only pick up the $1.6 \mu \mathrm{m}$ and the NDVI (red and NIR) bands. In theory, this algorithm can be implemented for any satellite sensor if provide reflectances in the appropriate bands. For other sensors, however, because the specification (such as center wavelength, bandwidth and spectral responses) of corresponding bands may be different with TANSO-CAI, the difference in the specification of bands must be corrected when applying to other satellites. The proposed algorithm is the first step towards the application of GOSAT data for the retrieval of AOD over land. We expect existing errors and the uncertainties in the algorithm to be improved in further studies by expanding experimental data, diversifying aerosol models in look-up tables, considering the effects of scattering angle, correcting elevated surface targets, and improving cloud detection algorithms. 
Acknowledgments: This study was supported by the National Natural Science Foundation of China (41401478). We are thankful to the GOSAT teams of Japan for providing TANSO-CAI data. We are grateful to the AERONET teams at the stations used in this paper. We also thank the LPDAAC for providing MODIS Thermal Anomalies/Fire products.

Author Contributions: Xiufeng Wang and Guosheng Zhong conceived the study and all authors contributed to its design. Xiufeng Wang, Hiroshi Tani, Meng Guo, Anthony R. Chittenden, and Shinji Matsumura supervised and provided technical support to the research. Shuai Yin and Zhongyi Sun assisted with the satellite and ground-based data collection. Guosheng Zhong performed the data analysis and wrote the paper.

Conflicts of Interest: The authors declare no conflict of interest.

\section{References}

1. Boucher, O.; Anderson, T.L. General circulation model assessment of the sensitivity of direct climate forcing by anthropogenic sulfate aerosols to aerosol size and chemistry. J. Geophys. Res. Atmos. 1995, 100, 26117-26134. [CrossRef]

2. Kaufman, Y.J.; Tanre, D.; Boucher, O. A satellite view of aerosols in the climate system. Nature 2002, 419, 215-223. [CrossRef] [PubMed]

3. Charlson, R.J.; Schwartz, S.E.; Hales, J.M.; Cess, R.D.; Coakley, J.A.; Hansen, J.E.; Hofmann, D.J. Climate forcing by anthropogenic aerosols. Science 1992, 255, 423-430. [CrossRef] [PubMed]

4. Kocifaj, M.; Horvath, H.; Jovanović, O.; Gangl, M. Optical properties of urban aerosols in the region Bratislava-Vienna I. methods and tests. Atmos. Environ. 2006, 40, 1922-1934. [CrossRef]

5. World Health Organization. Air Quality Guidelines for Europe; WHO Regional Office for Europe: Copenhagen, Danmark, 2000.

6. Wang, Z.; Chen, L.; Tao, J.; Zhang, Y.; Su, L. Satellite-based estimation of regional particulate matter (PM) in Beijing using vertical-and-RH correcting method. Remote Sens. Environ. 2010, 114, 50-63. [CrossRef]

7. Zhang, X.; Yang, L.; Yamaguchi, Y. Retrieval of aerosol optical depth over urban areas using Terra/MODIS data. ISPRS Int. Arch. Photogramm. Remote Sens. Spat. Inf. Sci. 2010, 38, 374-379.

8. Higurashi, A.; Nakajima, T. Development of a two-channel aerosol retrieval algorithm on a global scale using NOAA AVHRR. J. Atmos. Sci. 1999, 56, 924-941. [CrossRef]

9. Yu, H.; Kaufman, Y.; Chin, M.; Feingold, G.; Remer, L.; Anderson, T.; Balkanski, Y.; Bellouin, N.; Boucher, O.; Christopher, S. A review of measurement-based assessments of the aerosol direct radiative effect and forcing. Atmos. Chem. Phys. 2006, 6, 613-666. [CrossRef]

10. Kokhanovsky, A.; Breon, F.-M.; Cacciari, A.; Carboni, E.; Diner, D.; Di Nicolantonio, W.; Grainger, R.; Grey, W.; Höller, R.; Lee, K.-H. Aerosol remote sensing over land: A comparison of satellite retrievals using different algorithms and instruments. Atmos. Res. 2007, 85, 372-394. [CrossRef]

11. de Leeuw, G.; Holzer-Popp, T.; Bevan, S.; Davies, W.H.; Descloitres, J.; Grainger, R.G.; Griesfeller, J.; Heckel, A.; Kinne, S.; Klüser, L. Evaluation of seven European aerosol optical depth retrieval algorithms for climate analysis. Remote Sens. Environ. 2015, 162, 295-315. [CrossRef]

12. Riffler, M.; Popp, C.; Hauser, A.; Fontana, F.; Wunderle, S. Validation of a modified AVHRR aerosol optical depth retrieval algorithm over Central Europe. Atmos. Meas. Tech. 2010, 3, 1255-1270. [CrossRef]

13. King, M.D.; Kaufman, Y.J.; Tanré, D.; Nakajima, T. Remote sensing of tropospheric aerosols from space: Past, present, and future. Bull. Am. Meteorol. Soc. 1999, 80, 2229-2259. [CrossRef]

14. Holzer-Popp, T.; Schroedter, M.; Gesell, G. Retrieving aerosol optical depth and type in the boundary layer over land and ocean from simultaneous GOME spectrometer and ATSR-2 radiometer measurements, 1, method description. J. Geophys. Res. Atmos. 2002, 107, D21. [CrossRef]

15. Wang, Z.; Li, Q.; Wang, Q.; Li, S.; Chen, L.; Zhou, C.; Zhang, L.; Xu, Y. HJ-1 terrestrial aerosol data retrieval using deep blue algorithm. J. Remote Sens. 2012, 16, 596-610. (In Chinese)

16. Kaufman, Y.J.; Wald, A.E.; Remer, L.A.; Gao, B.-C.; Li, R.-R.; Flynn, L. The MODIS 2.1- $\mu$ m channel-correlation with visible reflectance for use in remote sensing of aerosol. IEEE Trans. Geosci. Remote Sens. 1997, 35, 1286-1298. [CrossRef]

17. Kaufman, Y.; Tanré, D.; Remer, L.A.; Vermote, E.; Chu, A.; Holben, B. Operational remote sensing of tropospheric aerosol over land from EOS moderate resolution imaging spectroradiometer. J. Geophys. Res. Atmos. 1997, 102, 17051-17067. [CrossRef] 
18. Soufflet, V.; Tanré, D.; Royer, A.; O'Neil, N. Remote sensing of aerosols over boreal forest and lake water from AVHRR data. Remote Sens. Environ. 1997, 60, 22-34. [CrossRef]

19. Dark Target (MODIS Aerosol Retrieval Algorithm): VIIRS. Available online: http:/ /darktarget.gsfc.nasa. gov/platforms/viirs (accessed on 8 July 2016).

20. Sun, L.; Wei, J.; Bilal, M.; Tian, X.; Jia, C.; Guo, Y.; Mi, X. Aerosol optical depth retrieval over bright areas using Landsat 8 OLI images. Remote Sens. 2016, 8, 23. [CrossRef]

21. Dark Target (MODIS Aerosol Retrieval Algorithm): What is the Difference between Dark Target and Deep Blue? Available online: http://darktarget.gsfc.nasa.gov/content/what-difference-between-dark-targetand-deep-blue (accessed on 18 July 2016).

22. Hsu, N.; Jeong, M.J.; Bettenhausen, C.; Sayer, A.; Hansell, R.; Seftor, C.; Huang, J.; Tsay, S.C. Enhanced deep blue aerosol retrieval algorithm: The second generation. J. Geophys. Res. Atmos. 2013, 118, 9296-9315. [CrossRef]

23. Holzer-Popp, T.; Schroedter-Homscheidt, M.; Breitkreuz, H.; Martynenko, D.; Klüser, L. Improvements of synergetic aerosol retrieval for ENVISAT. Atmos. Chem. Phys. 2008, 8, 7651-7672. [CrossRef]

24. Holzer-Popp, T.; Schroedter-Homscheidt, M.; Breitkreuz, H.; Klüser, L.; Martynenko, D. Synergistic aerosol retrieval from SCIAMACHY and AATSR onboard ENVISAT. Atmos. Chem. Phys. Discuss. 2008, 8, 1-49. [CrossRef]

25. Holzer-Popp, T.; Schroedter-Homscheidt, M. Synergetic aerosol retrieval from ENVISAT. In Proceedings of the ENVISAT \& ERS Symposium, Salzburg, Austria, 6-10 September 2004.

26. Mei, L.; Xue, Y.; Kokhanovsky, A.; von Hoyningen-Huene, W.; de Leeuw, G.; Burrows, J. Retrieval of aerosol optical depth over land surfaces from AVHRR data. Atmos. Meas. Tech. Discuss. 2013, 6, 2227-2251. [CrossRef]

27. Kaufman, Y.J.; Sendra, C. Algorithm for automatic atmospheric corrections to visible and near-IR satellite imagery. Int. J. Remote Sens. 1988, 9, 1357-1381. [CrossRef]

28. Kaufman, Y.J.; Tanre, D. Atmospherically resistant vegetation index (ARVI) for EOS-MODIS. IEEE Trans. Geosci. Remote Sens. 1992, 30, 261-270. [CrossRef]

29. Von Hoyningen-Huene, W.; Freitag, M.; Burrows, J. Retrieval of aerosol optical thickness over land surfaces from top-of-atmosphere radiance. J. Geophys. Res. Atmos. 2003, 108, D9. [CrossRef]

30. Global Greenhouse Gas Observation by Satellite Project (7th Edition (2016)). Available online: http:// www.gosat.nies.go.jp/eng/GOSAT_pamphlet_en.pdf (accessed on 18 May 2016).

31. Arai, K.; Sakashita, M. Evaluation of cirrus cloud detection accuracy of GOSAT/CAI and Landsat-8 with laser radar: Lidar and confirmation with Calipso data. Int. J. Adv. Res. Artifi. Intell. 2016, 5, 12-21. [CrossRef]

32. GOSAT/IBUKI Data Users Handbook 1st Edition. Available online: https://data.gosat.nies.go.jp/ GosatUserInterfaceGateway/guig/doc/GOSAT_HB_E_1stEdition_for_HP.pdf (accessed on 12 May 2016).

33. Jung, Y.; Kim, J.; Kim, W.; Boesch, H.; Lee, H.; Cho, C.; Goo, T.-Y. Impact of aerosol property on the accuracy of a $\mathrm{CO}_{2}$ retrieval algorithm from satellite remote sensing. Remote Sens. 2016, 8, 322. [CrossRef]

34. Algorithm Theoretical Basis Document (ATBD) for $\mathrm{CO}_{2}$ and $\mathrm{CH}_{4}$ Columun Amounts Retrieval from GOSAT TANSO-FTS SWIR. Available online: http://data.gosat.nies.go.jp/GosatUserInterfaceGateway/guig/doc/ documents/ATBD_FTSSWIRL2_V1.1_en.pdf (accessed on 22 May 2016).

35. Schaap, M.; Apituley, A.; Timmermans, R.; Koelemeijer, R.; de Leeuw, G. Exploring the relation between aerosol optical depth and pm 2.5 at Cabauw, The Netherlands. Atmos. Chem. Phys. 2009, 9, 909-925. [CrossRef]

36. Liu, Z.; Liu, Q.; Lin, H.C.; Schwartz, C.S.; Lee, Y.H.; Wang, T. Three-dimensional variational assimilation of MODIS aerosol optical depth: Implementation and application to a dust storm over East Asia. J. Geophys. Res. Atmos. 2011, 116, D23206. [CrossRef]

37. Schwartz, C.S.; Liu, Z.; Lin, H.C.; Cetola, J.D. Assimilating aerosol observations with a "hybrid" variational-ensemble data assimilation system. J. Geophys. Res. Atmos. 2014, 119, 4043-4069. [CrossRef]

38. Istomina, L.; von Hoyningen-Huene, W.; Kokhanovsky, A.; Schultz, E.; Burrows, J. Remote sensing of aerosols over snow using infrared AATSR observations. Atmos. Meas. Tech. 2011, 4, 1133-1145. [CrossRef]

39. Zhang, Y.; Li, Z.; Qie, L.; Zhang, Y.; Liu, Z.; Chen, X.; Hou, W.; Li, K.; Li, D.; Xu, H. Retrieval of aerosol fine-mode fraction from intensity and polarization measurements by PARASOL over East Asia. Remote Sens. 2016, 8, 417. [CrossRef] 
40. Wang, Z.; Gao, Z.; Li, Q.; Wang, W.; Chen, L.; Li, S. Urban aerosol monitoring over Ning-Bo from HJ-1. In Proceedings of the IEEE International Geoscience and Remote Sensing Symposium, Munich, Germany, 22-27 July 2012; pp. 2520-2523.

41. Wong, M.S.; Lee, K.-H.; Nichol, J.E.; Li, Z. Retrieval of aerosol optical thickness using MODIS, a study in Hong Kong and the Pearl River Delta Region. IEEE Trans. Geosci. Remote Sens. 2010, 48, 3318-3327. [CrossRef]

42. Kuze, A.; O’Brien, D.M.; Taylor, T.E.; Day, J.O.; O’Dell, C.W.; Kataoka, F.; Yoshida, M.; Mitomi, Y.; Bruegge, C.J.; Pollock, H. Vicarious calibration of the GOSAT sensors using the railroad valley desert playa. IEEE Trans. Geosci. Remote Sens. 2011, 49, 1781-1795. [CrossRef]

43. Huo, J.; Zhang, W.; Zeng, X.; Lü, D.; Liu, Y. Examination of the quality of GOSAT/CAI cloud flag data over Beijing using ground-based cloud data. Adv. Atmos. Sci. 2013, 30, 1526-1534. [CrossRef]

44. Fukuda, S.; Nakajima, T.; Takenaka, H.; Higurashi, A.; Kikuchi, N.; Nakajima, T.Y.; Ishida, H. New approaches to removing cloud shadows and evaluating the $380 \mathrm{~nm}$ surface reflectance for improved aerosol optical thickness retrievals from the GOSAT/TANSO-cloud and aerosol imager. J. Geophys. Res. Atmos. 2013, 118, 13520-13531. [CrossRef]

45. Algorithm Theoretical Basis Document (ATBD) on the Processing of GOSAT TANSO-CAI L3 Global Reflectance Products. Available online: https://data.gosat.nies.go.jp/GosatWebDds/productorder/ distribution/user/ATBD_CAIL3REF_V1.0_en.pdf (accessed on 29 May 2016).

46. Algorithm Theoretical Basis Document for TANSO-CAI L1B Processing. Available online: https://data. gosat.nies.go.jp/GosatWebDds/productorder/distribution/user/ATBD_CAIL1B_V1.0_en.pdf (accessed on 23 May 2016).

47. Algorithm Theoretical Basis Document for TANSO-CAI L1B+ Processing. Available online: https://data. gosat.nies.go.jp/GosatWebDds/productorder/distribution/user/ATBD_CAIL1BP_V1.01_en.pdf (accessed on 26 May 2016).

48. NIES GOSAT Product Format Descriptions. Available online: https:/ /data.gosat.nies.go.jp/GosatWebDds / productorder/distribution/user/GOSAT_ProductDescription_V1.50_en.pdf (accessed on 17 May 2015).

49. Holben, B.N.; Eck, T.; Slutsker, I.; Tanre, D.; Buis, J.; Setzer, A.; Vermote, E.; Reagan, J.A.; Kaufman, Y.; Nakajima, T. AERONET-A federated instrument network and data archive for aerosol characterization. Remote Sens. Environ. 1998, 66, 1-16. [CrossRef]

50. Chen, H.; Cheng, T.; Gu, X.; Li, Z.; Wu, Y. Evaluation of polarized remote sensing of aerosol optical thickness retrieval over China. Remote Sens. 2015, 7, 13711-13728. [CrossRef]

51. Homepage of Aerosol Robotic Network. Available online: http://aeronet.gsfc.nasa.gov/new_web/ index.html (accessed on 11 May 2016).

52. Ångström, A. The parameters of atmospheric turbidity. Tellus 1964, 16, 64-75. [CrossRef]

53. Vermote, E.F.; El Saleous, N.Z.; Justice, C.O. Atmospheric correction of MODIS data in the visible to middle infrared: First results. Remote Sens. Environ. 2002, 83, 97-111. [CrossRef]

54. Vermote, E.F.; Kotchenova, S. Atmospheric correction for the monitoring of land surfaces. J. Geophys. Res. Atmos. 2008, 113. [CrossRef]

55. Fu, Q.; Min, X.; Sun, L.; Ma, S. Atmospheric correction of HJ-1 A/B CCD over land: Land surface reflectance calculation for geographical information product. J. Geogr. Sci. 2014, 24, 1083-1094. [CrossRef]

56. Liang, S.; Fang, H.; Chen, M. Atmospheric correction of LANDSAT ETM+ land surface imagery. I. Methods. IEEE Trans. Geosci. Remote Sens. 2001, 39, 2490-2498. [CrossRef]

57. Vermote, E.F.; Tanré, D.; Deuze, J.L.; Herman, M.; Morcette, J.-J. Second simulation of the satellite signal in the solar spectrum, 6S: An overview. IEEE Trans. Geosci. Remote Sens. 1997, 35, 675-686. [CrossRef]

58. Kotchenova, S.Y.; Vermote, E.F.; Levy, R.; Lyapustin, A. Radiative transfer codes for atmospheric correction and aerosol retrieval: Intercomparison study. Appl. Opt. 2008, 47, 2215-2226. [CrossRef] [PubMed]

59. Callieco, F.; Dell'Acqua, F. A comparison between two radiative transfer models for atmospheric correction over a wide range of wavelengths. Int. J. Remote Sens. 2011, 32, 1357-1370. [CrossRef]

60. Vermote, E.; Tanré, D.; Deuzé, J.; Herman, M.; Morcrette, J.; Kotchenova, S. Second simulation of a satellite signal in the solar spectrum-vector (6sv). 65 User Guide Version 2006, 3, 1-55.

61. Levy, R.C.; Remer, L.A.; Mattoo, S.; Vermote, E.F.; Kaufman, Y.J. Second-generation operational algorithm: Retrieval of aerosol properties over land from inversion of moderate resolution imaging spectroradiometer spectral reflectance. J. Geophys. Res. Atmos. 2007, 112, D13211. [CrossRef] 
62. Homepage of NASA Earth Observatory. Available online: http:/ / earthobservatory.nasa.gov/Features / MeasuringVegetation/measuring_vegetation_2.php (accessed on 23 October 2016).

63. Algorithm for Remote Sensing of Tropospheric Aerosol from MODIS: Collection 5. Available online: http://modis.gsfc.nasa.gov/data/atbd/atbd_mod02.pdf (accessed on 20 May 2015).

64. Rouse, J.W.; Haas, R.H.; Deering, D.W.; Sehell, J.A. Monitoring the Vernal Advancement and Retrogradation (Green Wave Effect) of Natural Vegetation; Remote Sensing Center: Texas A\&M University, College Station, TX, USA, 1974.

65. Ogutu, B.O.; Dash, J. An algorithm to derive the fraction of photosynthetically active radiation absorbed by photosynthetic elements of the canopy (FAPARps) from eddy covariance flux tower data. New Phytol. 2013, 197, 511-523. [CrossRef] [PubMed]

66. Liu, G.-R.; Liang, C.-K.; Kuo, T.-H.; Lin, T.-H.; Huang, S. Comparison of the NDVI, ARVI and AFRI vegetation index, along with their relations with the AOD using SPOT 4 vegetation dat. Terr. Atmos. Ocean. Sci. 2004, 15, 15-32.

67. Zhou, L.; Kaufmann, R.; Tian, Y.; Myneni, R.; Tucker, C. Relation between interannual variations in satellite measures of northern forest greenness and climate between 1982 and 1999. J. Geophys. Res. Atmos. 2003, 108, D1. [CrossRef]

68. Karnieli, A.; Kaufman, Y.J.; Remer, L.; Wald, A. Afri-Aerosol free vegetation index. Remote Sens. Environ. 2001, 77, 10-21. [CrossRef]

69. Ben-Ze'ev, E.; Karnieli, A.; Agam, N.; Kaufman, Y.; Holben, B. Assessing vegetation condition in the presence of biomass burning smoke by applying the aerosol-free vegetation index (AFRI) on MODIS images. Int. J. Remote Sens. 2006, 27, 3203-3221. [CrossRef]

70. Vermote, E.; Vermeulen, A. Atmospheric Correction Algorithm: Spectral Reflectances (MOD09), ATBD version 4.0, 1999. Available online: http://modis.gsfc.nasa.gov/data/atbd/atbd_mod08.pdf (accessed on 5 May 2016).

71. Tripathi, S.; Dey, S.; Chandel, A.; Srivastava, S.; Singh, R.P.; Holben, B. Comparison of MODIS and AERONET derived aerosol optical depth over the Ganga Basin, India. Ann. Geophys. 2005, 23, 1093-1101. [CrossRef]

72. Tiwari, S.; Singh, A. Variability of aerosol parameters derived from ground and satellite measurements over Varanasi located in the Indo-Gangetic Basin. Aerosol Air Qual. Res. 2013, 13, 627-638. [CrossRef]

73. Giglio, L. MODIS Collection 5 Active Fire Product User's Guide Version 2.4. 2010. Available online: http://www.fao.org/fileadmin/templates/gfims/docs/MODIS_Fire_Users_Guide_2.4.pdf (accessed on 22 May 2016).

74. Khatiwada, K.R.; Panthi, J.; Shrestha, M.L.; Nepal, S. Hydro-climatic variability in the Karnali River Basin of Nepal Himalaya. Climate 2016, 4, 17. [CrossRef]

75. Witek, M.L.; Garay, M.J.; Diner, D.J.; Smirnov, A. Aerosol optical depths over oceans: A view from MISR retrievals and collocated MAN and AERONET in situ observations. J. Geophys. Res. Atmos. 2013, 118, 12620-12633. [CrossRef]

76. Petrenko, M.; Ichoku, C.; Leptoukh, G. Multi-sensor aerosol products sampling system (MAPSS). Atmos. Meas. Tech. 2012, 5, 913-926. [CrossRef]

77. More, S.; Pradeep Kumar, P.; Gupta, P.; Devara, P.; Aher, G. Comparison of aerosol products retrieved from AERONET, MICROTOPS and MODIS over a tropical urban city, Pune, India. Aerosol Air Qual. Res. 2013, 13, 107-121. [CrossRef]

78. Shi, Y.; Zhang, J.; Reid, J.; Holben, B.; Hyer, E.; Curtis, C. An analysis of the collection 5 MODIS over-ocean aerosol optical depth product for its implication in aerosol assimilation. Atmos. Chem. Phys. 2011, 11, 557-565. [CrossRef]

79. Shi, Y.; Zhang, J.; Reid, J.; Hyer, E.; Hsu, N. Critical evaluation of the MODIS deep blue aerosol optical depth product for data assimilation over North Africa. Atmos. Meas. Tech. 2013, 6, 949-969. [CrossRef]

80. Willmott, C.J.; Matsuura, K. Advantages of the mean absolute error (MAE) over the root mean square error (RMSE) in assessing average model performance. Clim. Res. 2005, 30, 79-82. [CrossRef]

81. Levy, R.C.; Remer, L.A.; Kleidman, R.G.; Mattoo, S.; Ichoku, C.; Kahn, R.; Eck, T. Global evaluation of the collection 5 MODIS dark-target aerosol products over land. Atmos. Chem. Phys. 2010, 10, 10399-10420. [CrossRef]

82. Chu, D.; Kaufman, Y.; Ichoku, C.; Remer, L.; Tanré, D.; Holben, B. Validation of MODIS aerosol optical depth retrieval over land. Geophys. Res. Lett. 2002, 29, 12. [CrossRef] 
83. Remer, L.A.; Kaufman, Y.; Tanré, D.; Mattoo, S.; Chu, D.; Martins, J.V.; Li, R.-R.; Ichoku, C.; Levy, R.; Kleidman, R. The MODIS aerosol algorithm, products, and validation. J. Atmos. Sci. 2005, 62, 947-973. [CrossRef]

84. Ruiz-Arias, J.; Dudhia, J.; Gueymard, C.; Pozo-Vázquez, D. Assessment of the level-3 MODIS daily aerosol optical depth in the context of surface solar radiation and numerical weather modeling. Atmos. Chem. Phys. 2013, 13, 675-692. [CrossRef]

85. Nichol, J.E.; Bilal, M. Validation of modis $3 \mathrm{~km}$ resolution aerosol optical depth retrievals over Asia. Remote Sens. 2016, 8, 328. [CrossRef]

86. Calinoiu, D.; Ionel, I.; Triftordai, G. Analysis of aerosol optical thickness in timisoara from aeronet global network observations. Strojarstvo 2011, 53, 353-358.

87. Xie, Y.; Zhang, Y.; Xiong, X.; Qu, J.J.; Che, H. Validation of MODIS aerosol optical depth product over China using CARSNET measurements. Atmos. Environ. 2011, 45, 5970-5978. [CrossRef]

88. Zhang, H.; Hoff, R.; Kondragunta, S.; Laszlo, I.; Lyapustin, A. Aerosol optical depth (AOD) retrieval using simultaneous GOES-East and GOES-West reflected radiances over the western United States. Atmos. Meas. Tech. 2013, 6, 471-486. [CrossRef]

(C) 2016 by the authors; licensee MDPI, Basel, Switzerland. This article is an open access article distributed under the terms and conditions of the Creative Commons Attribution (CC-BY) license (http:/ / creativecommons.org/licenses/by/4.0/). 